\title{
Surface ablation and its drivers along a west-east transect of the Southern Patagonia Icefield
}

\section{Article \\ Cite this article: Bravo C, Ross AN, Quincey DJ, Cisternas S, Rivera A (2022). Surface ablation and its drivers along a west-east transect of the Southern Patagonia Icefield. Journal of Glaciology 68(268), 305-318. https:// doi.org/10.1017/jog.2021.92}

Received: 21 January 2021

Revised: 14 July 2021

Accepted: 15 July 202

First published online: 9 August 2021

Keywords:

Energy balance; glacier modelling; meltsurface

Author for correspondence:

Claudio Bravo, E-mail: cbravo@cecs.cl (c) The Author(s), 2021. Published by Cambridge University Press. This is an Open Access article, distributed under the terms of the Creative Commons Attribution licence (http://creativecommons.org/licenses/by/4.0/), which permits unrestricted re-use, distribution, and reproduction in any medium, provided the original work is properly cited.
Claudio Bravo ${ }^{1,2}\left(\mathbb{0}\right.$, Andrew N. Ross ${ }^{3}$, Duncan J. Quincey ${ }^{1}$, Sebastián Cisternas ${ }^{2}$ and Andrés Rivera ${ }^{4}$ (B)

\footnotetext{
${ }^{1}$ School of Geography, University of Leeds, Leeds, UK; ${ }^{2}$ Centro de Estudios Científicos, CECs, Valdivia, Chile; ${ }^{3}$ School of Earth and Environment, University of Leeds, Leeds, UK and ${ }^{4}$ Departamento de Geografía, Universidad de Chile, Santiago, Chile
}

\section{Abstract}

Glaciers in the Southern Patagonia Icefield (SPI) have been shrinking in recent decades, but due to a lack of field observations, understanding of the drivers of ablation is limited. We present a distributed surface energy balance model, forced with meteorological observations from a westeast transect located in the north of the SPI. Between October 2015 and June 2016, humid and warm on-glacier conditions prevailed on the western side compared to dry and cold conditions on the eastern side. Controls of ablation differ along the transect, although at glacier-wide scale sensible heat (mean of $72 \mathrm{~W} \mathrm{~m}^{-2}$ to the west and $51 \mathrm{~W} \mathrm{~m}^{-2}$ to the east) and net shortwave radiation (mean of $54 \mathrm{~W} \mathrm{~m}^{-2}$ to the west and $52 \mathrm{~W} \mathrm{~m}^{-2}$ to the east) provided the main energy sources. Net longwave radiation was an energy sink, while latent heat was the most spatially variable flux, being an energy sink in the east $\left(-4 \mathrm{~W} \mathrm{~m}^{-2}\right)$ and a source in the west $\left(20 \mathrm{~W} \mathrm{~m}^{-2}\right)$. Ablation was high, but at comparable elevations, it was greater to the west. These results provide new insights into the spatial variability of energy-balance fluxes and their control over the ablation of Patagonian glaciers.

\section{Introduction}

Patagonia $\left(40-55^{\circ} \mathrm{S}\right)$ comprises the most extensive icefields at mid-latitudes in the Southern Hemisphere: the Southern Patagonia Icefield (SPI) and the Northern Patagonia Icefield (NPI). Glacier wastage in this region (Rignot and others, 2003; Davies and Glasser, 2012; Willis and others, 2012; White and Copland, 2015; Foresta and others, 2018; Malz and others, 2018; Abdel Jaber and others, 2019; Braun and others, 2019; Dussaillant and others, 2019) is a matter of concern due to its observed and potential contribution to sea-level rise (Gardner and others, 2013; Zemp and others, 2019; Masiokas and others, 2020) and the role of receding glaciers in triggering hazardous natural events such as glacial-lake outburst floods (Wilson and others, 2018) and rock avalanche events associated with de-buttressing (Iribarren-Anacona and others, 2015).

The SPI is the largest continuous ice mass along the Andes with a total area of $12232 \pm 201$ $\mathrm{km}^{2}$ (Meier and others, 2018, Fig. 1). The large glaciers are mostly lacustrine-calving towards the east and marine-terminating to the west. This icefield has been the focus of several geodetic mass-balance estimates in recent years. Despite some differences in their magnitude and spatial variability, these geodetic mass balances agree that the SPI as a whole is losing mass, irrespective of the observation period (e.g. Rignot and others, 2003; Willis and others, 2012; Malz and others, 2018; Braun and others, 2019; Dussaillant and others, 2019). However, a number of glaciers in the SPI are stable, so a glacier response is best described as heterogeneous (Foresta and others, 2018; Abdel-Jaber and others, 2019). Dynamical adjustments associated with calving glaciers have been invoked as a key control of the overall ice losses (Mouginot and Rignot, 2015; Braun and others, 2019) supported by observations that land-terminating glaciers outside the icefields show less mass loss (e.g. Falaschi and others, 2017, 2019) despite being exposed to the same climatic forcing (Braun and others, 2019). Moreover, surface massbalance modelling forced with climate data shows positive mean values for the entire SPI (Schaefer and others, 2015; Mernild and others, 2016), leading to questions around how the mass balance of glaciers in this region will evolve over coming decades.

Studies based on direct in situ observations that characterise the fundamental meteorological and glacier conditions needed for surface mass balance and energy-balance models are, however, extremely limited in number in this region (Masiokas and others, 2020). Direct mass-balance measurements using the glaciological method are equally scarce. This means that high uncertainty exists in earlier modelling efforts, as no on-glacier observations have been available to validate the meteorological variables used to drive and parameterise these models (e.g. Schaefer and others, 2015; Mernild and others, 2016). Additionally, efforts to estimate the sensitivity of these glaciers to climate changes have been made using coarseclimate models and re-analysis (e.g. Cook and others, 2003; Rasmussen and others, 2007; Sagredo and Lowell, 2012) which do not capture the finer details and spatial differences of the drivers of the surface mass balance. Consequently, our understanding of how glaciers 
are responding to changes in climate over this important region of the Andes is limited (Pellicciotti and others, 2014).

A notable characteristic in Patagonia that defines the meteorological conditions is the orographic effect. This effect has been described at a regional scale, especially in terms of precipitation and water vapour. Due to the mechanical effect of the mountain chain, the air ascends in the western sector (windward) favouring conditions for saturation and hence the occurrence of precipitation, while subsidence of the air and inhibition of the precipitation occurs in the eastern sector (leeward) (Schneider and others, 2003; Smith and Evans, 2007; Garreaud and others, 2013; Lenaerts and others, 2014). However, it seems that the orographic effect also has direct effects at the scale of the SPI, forcing meteorological conditions that are distinct from one side of the icefield to the other.

The most evident impact of the orographic effect is the difference in cloud cover and its impact on the magnitude of the incoming shortwave radiation on both sides of the SPI (Schaefer and others, 2015). It has been shown that distinct lapse rates prevail between western and eastern glaciers which in turn has implications for the estimation of surface ablation (Bravo and others, 2019a). Additional insights of the spatial differences in the SPI come from remote-sensing analyses, which suggest the influence of humid conditions is manifested by differing snow facies on either side of the divide (De Angelis and others, 2007) and also in differences in the timing of melt season onset, being earlier in the west compared to the east (Monahan and Ramage, 2010).

To assess how the meteorological differences forced by the orographic effect impact surface ablation, we present a distributed surface energy balance (SEB) model for glaciers located in the northern section of the SPI $\left(48-49^{\circ} \mathrm{S}\right)$ and on both sides of the divide. The aim is to increase our understanding of the processes and fluxes controlling surface ablation and its spatial differences. For this purpose, we used meteorological observations collected by automatic weather stations (AWSs) between October 2015 and June 2016 at several locations (Fig. 1).

\section{Materials and methods}

\subsection{Automatic weather stations}

The observational network consists of five AWSs installed in proglacial zones and nunataks on the plateau of the SPI along a west-east transect $\sim 48^{\circ} \mathrm{S}$ (Fig. 1). Also, three air temperature sensors and ultrasonic depth gauges (UDGs) were installed over the glacier surface in the so-called Glacier Boundary Layer stations (GBL; Fig. 1 and Table 1). The UDGs at GBL1 and GBL2 were primarily used to compare with our computed ablation values. The broader network allowed us to describe the spatial and temporal variabilities under meteorological conditions, as well as to calculate the components of the SEB. Table 1 shows the details of each AWS, including the sensors and locations. Details of the characteristics of the locations of each AWS are given in Bravo and others (2019a).

\subsection{Distribution of meteorological variables}

The spatial coverage of the AWS network made it possible to distribute the meteorological variables that were needed to force the SEB. We used elevation gradients as the main method of spatial distribution of meteorological variables (Table 2). TanDEM-X digital elevation data acquired by the German Aerospace Center (DLR) in the years 2012 and 2015 (Abdel-Jaber and others, 2019) and gridded at $200 \mathrm{~m}$ resolution, were used to distribute the meteorological variables and to estimate radiation fluxes.
The glacier outlines were obtained from the inventory of De Angelis (2014), but frontal positions and margins were manually updated based on a cloud-free Landsat- 8 OLI satellite image acquired on 1 April 2014.

The meteorological variables and factors related to cloud cover were taken from the AWS observations (Table 1). We assumed that the AWS observations installed on the west side (GT, HSNO) were representative of glaciers Témpano $\left(327 \mathrm{~km}^{2}\right)$, Occidental $\left(218 \mathrm{~km}^{2}\right)$, Greve $\left(412 \mathrm{~km}^{2}\right)$, HPS $8\left(34 \mathrm{~km}^{2}\right)$ and one unnamed glacier $\left(41 \mathrm{~km}^{2}\right)$. AWSs installed on the east side (GO, HSO) were considered representative of glaciers O'Higgins (751 $\left.\mathrm{km}^{2}\right)$, Pirámide $\left(27 \mathrm{~km}^{2}\right)$ and Chico $\left(229 \mathrm{~km}^{2}\right)$. HSG AWS was considered as representative of the conditions at the ice divide.

Air temperature was distributed using hourly lapse rates between each pair of AWS. A bias-correction was applied considering that the observations were taken on relatively small rock surfaces surrounded by ice (nunataks), meaning that the glacier cooling effect (i.e. cooling of the near-surface air layers in comparison with the ambient off-glacier conditions and induced by the glacier surface; Carturan and others, 2015) is not included directly in the air temperature observations. Based on the findings of Bravo and others (2019a), the bias-correction applied was $1^{\circ} \mathrm{C}$ at the west side and $3^{\circ} \mathrm{C}$ at the east side. Further details of the air temperature observations, lapse rates and bias-correction are given in Bravo and others (2019a).

The AWS network offered the possibility to distribute humidity, rather than assume a constant value (e.g. Braun and Hock, 2004; Fyffe and others, 2014). Considering the extreme meteorological gradients observed in the Patagonian region, an adequate representation of the humidity conditions at both sides of the SPI is critical to increasing our understanding of the meteorological factors controlling ablation. The distributed relative humidity was calculated using air vapour pressure $\left(e_{\mathrm{a}}\right)$ and air saturation vapour pressure $\left(e_{\text {sat }}\right)$ as separate components. For each AWS, we calculated the air water vapour pressure, using the observed $(2 \mathrm{~m})$ relative humidity $(f)$ and air temperature $\left(T_{\mathrm{a}}\right)$, as follows:

$$
e_{\mathrm{a}}=e_{\mathrm{sat}} \frac{f}{100}
$$

where $e_{\text {sat }}$ according to the empirical formula of ClausiusClapeyron (Bolton, 1980), is only a function of $T_{\mathrm{a}}$ in ${ }^{\circ} \mathrm{C}$ :

$$
e_{\text {sat }}\left(T_{\mathrm{a}}\right)=6.112 \exp \left(\frac{17.67 T_{\mathrm{a}}}{T_{\mathrm{a}}+243.5}\right),
$$

Air water vapour pressure was fitted against elevation (Shea and Moore, 2010) and hourly gradients were obtained. Mean gradient values of the air water vapour pressure were $-0.84 \mathrm{hPa} \mathrm{km}^{-1}$ on the east side and $-2.80 \mathrm{hPa} \mathrm{km}^{-1}$ on the west side. Typical values of hourly gradients observed in glaciers elsewhere were between -6 and $-1 \mathrm{hPa} \mathrm{km}^{-1}$ (Shea and Moore, 2010). Hence, our eastern gradient was slightly outside this typical range.

The atmospheric pressure was distributed using the hydrostatic equation (Wallace and Hobbs, 2006) that relates two elevations and pressure levels and allows correction of the atmospheric pressure to a reference level (e.g. sea level).

To estimate the surface temperature $\left(T_{\mathrm{s}}\right)$, we used as a proxy the dew point temperature $\left(T_{\mathrm{d}}\right)$ for the snow surface and the assumption of constant surface temperature $\left(0^{\circ} \mathrm{C}\right)$ under melt conditions on glacier surfaces, namely when the air temperature is positive (Oerlemans and Klok, 2002). The $T_{\mathrm{d}}$ approach calculated at a standard height is a reasonable first-order approximation of daily $T_{\mathrm{s}}$ (Raleigh and others, 2013), but here it was 

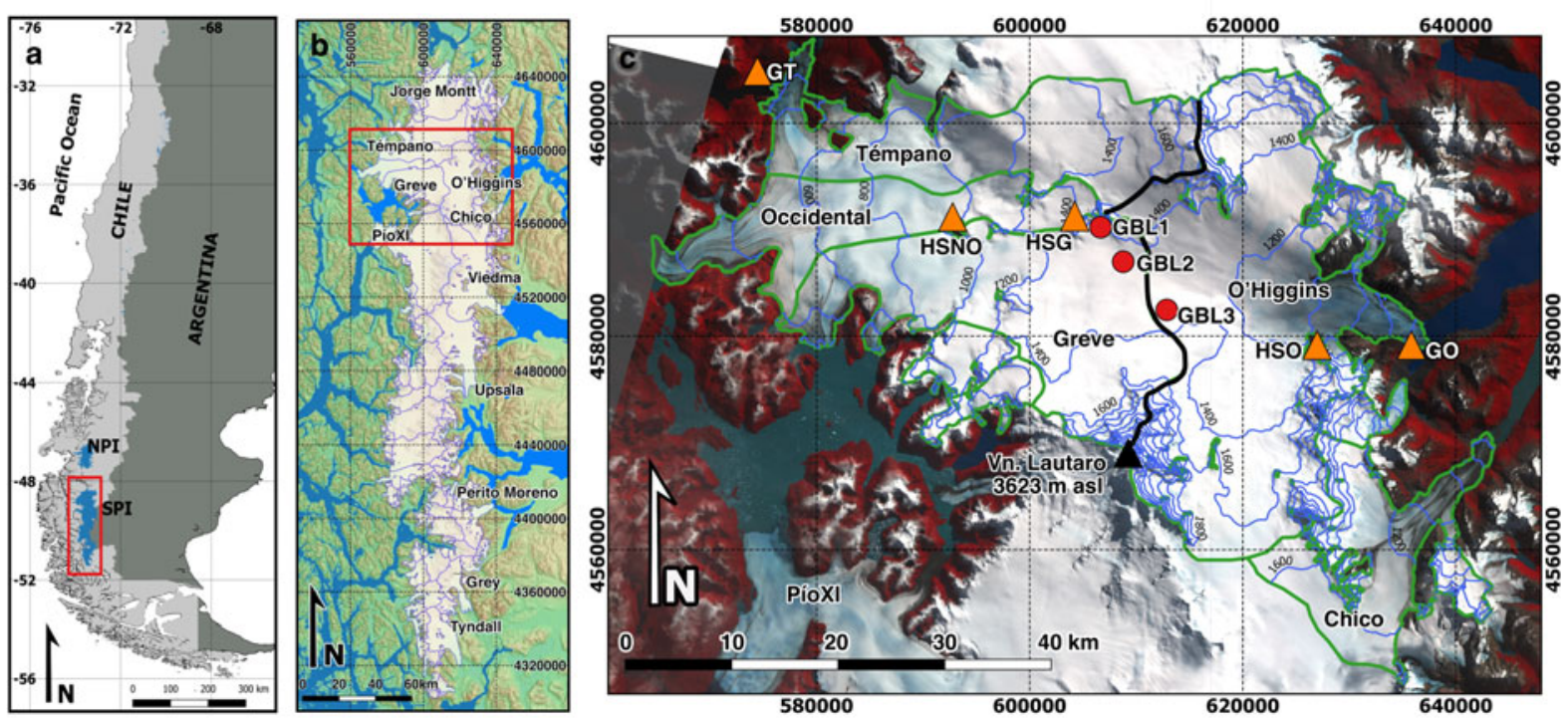

Fig. 1. (a) Southern South America, NPI and SPI are the Northern and Southern Patagonia Icefields, respectively. (b) SPI overlying a hillshade map of the region obtained from SRTM. (c) Study area and locations of the observational network in a Landsat-8 OLI acquired on 1 April 2014. Symbols are AWSs (triangles) and GBL stations (red circles). Green lines denote the glacier boundaries and black line is the ice divide. Image coordinates are UTM18-S, WGS-1984.

Table 1. Locations and details of the sensors for each AWS

\begin{tabular}{|c|c|c|c|c|c|c|}
\hline $\begin{array}{l}\text { AWS lat/lon/elevation ( } \mathrm{m} \text { a.s.l.) } \\
\text { SPI margin/surface type, height } \\
\mathrm{m}\end{array}$ & $\begin{array}{l}\text { Air temperature } \\
\text { and relative } \\
\text { humidity }\end{array}$ & Wind speed & $\begin{array}{l}\text { Atmospheric } \\
\text { pressure }\end{array}$ & $\begin{array}{l}\text { Incoming } \\
\text { shortwave } \\
\text { radiation }\end{array}$ & $\begin{array}{l}\text { Incoming } \\
\text { longwave } \\
\text { radiation }\end{array}$ & Period \\
\hline $\begin{array}{l}\text { Glaciar Témpano (GT) } \\
48^{\circ} 42^{\prime} 09^{\prime \prime} \mathrm{S} / 73^{\circ} 59^{\prime} 17^{\prime} \mathrm{W} / 50 \\
\text { West/Rock, } 2\end{array}$ & Young 41382VC & RM Young 5103 & $\mathrm{n} / \mathrm{a}$ & $\mathrm{n} / \mathrm{a}$ & $n / a$ & $\begin{array}{l}1 \text { October } 2015 \\
30 \text { June } 2016\end{array}$ \\
\hline $\begin{array}{l}\text { Hielo Sur Glaciar Greve, Nunatak Occidental (HSNO) } \\
48^{\circ} 49^{\prime} 59^{\prime \prime} \mathrm{S} / 73^{\circ} 43^{\prime} 25^{\prime \prime} \text { W/ } 1040 \\
\text { West, nunatak/Rock, } 2\end{array}$ & Rotronic $\mathrm{HC2}-\mathrm{S} 3$ & RM Young 5103 & Setra 278 & CMP3 & CGR3 & $\begin{array}{l}1 \text { October } 2015 \\
30 \text { June } 2016\end{array}$ \\
\hline $\begin{array}{l}\text { Hielo Sur Glaciar Greve (HSG) } \\
48^{\circ} 49^{\prime} 55^{\prime \prime} \text { S/ } 73^{\circ} 34^{\prime} 53^{\prime \prime} \text { W/ } 1428 \\
\text { Divide, nunatak/Rock, } 2\end{array}$ & Young 41382VC & RM Young 5103 & $\begin{array}{l}\text { Vaisala } \\
\text { PTB110 }\end{array}$ & CMP3 & $n / a$ & $\begin{array}{l}1 \text { October } 2015 \\
30 \text { June } 2016\end{array}$ \\
\hline $\begin{array}{l}\text { Hielo Sur Glaciar O’Higgins (HSO) } \\
48^{\circ} 55^{\prime} 28^{\prime \prime} \mathrm{S} / 73^{\circ} 16^{\prime} 26^{\prime \prime} \mathrm{W} / 1234 \\
\text { East, nunatak/Rock, } 2\end{array}$ & Rotronic HC2-S3 & RM Young 5103 & $\begin{array}{l}\text { Vaisala } \\
\text { PTB110 }\end{array}$ & CMP3 & CGR3 & $\begin{array}{l}17 \text { October } 2015 \\
30 \text { June } 2016\end{array}$ \\
\hline $\begin{array}{l}\text { Glaciar O 'Higgins (GO) } \\
48^{\circ} 55^{\prime} 47^{\prime \prime} \mathrm{S} / 73^{\circ} 08^{\prime} 21^{\prime} \mathrm{W} / 310 \\
\text { East/Rock, } 2\end{array}$ & Young 41382VC & RM Young 5103 & $\begin{array}{l}\text { Vaisala } \\
\text { PTB110 }\end{array}$ & CMP3 & CGR3 & $\begin{array}{l}1 \text { October } 2015 \\
30 \text { June } 2016\end{array}$ \\
\hline $\begin{array}{l}\text { GBL station } 1(\mathrm{GBL} 1) \\
48^{\circ} 50^{\prime} 02^{\prime \prime} \mathrm{S} / 73^{\circ} 34^{\prime} 51^{\prime \prime} \mathrm{W} / 1415 \\
\text { West, plateau/glacier, } 1.2\end{array}$ & Thermistor 107-L & $\mathrm{n} / \mathrm{a}$ & $\mathrm{n} / \mathrm{a}$ & $\mathrm{n} / \mathrm{a}$ & $\mathrm{n} / \mathrm{a}$ & $\begin{array}{l}17 \text { October } 2015 \\
15 \text { February } 2016\end{array}$ \\
\hline $\begin{array}{l}\text { GBL station } 2(\mathrm{GBL} 2) \\
48^{\circ} 51^{\prime} 34^{\prime \prime} \mathrm{S} / 73^{\circ} 31^{\prime} 37^{\prime \prime} \mathrm{W} / 1294 \\
\text { West, plateau/glacier, } 2\end{array}$ & Thermistor 107-L & $\mathrm{n} / \mathrm{a}$ & $\mathrm{n} / \mathrm{a}$ & $\mathrm{n} / \mathrm{a}$ & $\mathrm{n} / \mathrm{a}$ & $\begin{array}{l}25 \text { October } 2015 \\
31 \text { March } 2016\end{array}$ \\
\hline $\begin{array}{l}\text { GBL station } 3(\mathrm{GBL} 3) \\
48^{\circ} 54^{\prime} 30^{\prime \prime} \mathrm{S} / 73^{\circ} 27^{\prime} 47^{\prime \prime} \mathrm{W} / 1378 \\
\text { East, plateau/ glacier, } 2\end{array}$ & Thermistor $109-\mathrm{L}$ & $\mathrm{n} / \mathrm{a}$ & $\mathrm{n} / \mathrm{a}$ & $\mathrm{n} / \mathrm{a}$ & $\mathrm{n} / \mathrm{a}$ & $\begin{array}{l}10 \text { April } 2016 \\
30 \text { June } 2016\end{array}$ \\
\hline
\end{tabular}

$\mathrm{n} / \mathrm{a}$, not available measurements.

computed at hourly time step using the Magnus-Tetens approach (Murray, 1967, Raleigh and others, 2013):

$$
T_{\mathrm{s}}=T_{\mathrm{d}}=\frac{c\left[\ln (f)+\left(b T_{\mathrm{a}} /\left(c+T_{\mathrm{a}}\right)\right)\right]}{b-\ln (f)-\left(b T_{\mathrm{a}} /\left(c+T_{\mathrm{a}}\right)\right)},
$$

As the aim was to estimate snow surface temperature when $T_{\mathrm{a}}<0^{\circ} \mathrm{C}$, the coefficients used were $b=22.587$ and $c=273.86^{\circ} \mathrm{C}$ (Raleigh and others, 2013). Figure S1 shows the relationship between air temperature and dew point temperature for different values of relative humidity.

When the air temperature was equal to zero or positive, the snow/ice surface temperature was fixed to $0^{\circ} \mathrm{C}$ and the surface 
Table 2. Methods, assumptions and approach references used to distribute the meteorological data over the glaciers on the SPI

\begin{tabular}{|c|c|c|c|c|c|}
\hline Variable & Symbol & Units & Method/assumption & Time step & Approach reference \\
\hline Air temperature & $T_{a}$ & ${ }^{\circ} \mathrm{C}$ & Observed lapse rate & Hourly & Bravo and others (2019b) \\
\hline Surface temperature & $T_{s}$ & ${ }^{\circ} \mathrm{C}$ & $\begin{array}{l}\text { Dew point air temperature as proxy of snow surface temperature. } \\
\text { Surface temperature set to zero when } T_{a}>0\end{array}$ & Daily & Raleigh and others (2013) \\
\hline Atmospheric pressure & $P$ & $\mathrm{~Pa}$ & Hydrostatic equation & Hourly & Wallace and Hobbs (2006) \\
\hline Air vapour pressure & $e_{a}$ & $\mathrm{~Pa}$ & Observed gradient & Hourly & Shea and Moore (2010) \\
\hline Saturation vapour pressure & $e_{\text {sat }}$ & $\mathrm{Pa}$ & Function of air temperature & Hourly & Bolton (1980) \\
\hline Surface vapour pressure & $e_{s}$ & $\mathrm{~Pa}$ & $\begin{array}{l}\text { Under sub-zero conditions, saturation of the surface layer. Set to } \\
6.11 \mathrm{hPa} \text { when } T_{\mathrm{s}}=0\end{array}$ & Hourly & Brock and Arnold (2000) \\
\hline Wind speed & $u$ & $\mathrm{~ms}^{-1}$ & Observed lapse rate & Hourly & Fyffe and others (2014) \\
\hline
\end{tabular}

water vapour pressure $\left(e_{\mathrm{s}}\right)$ was fixed to $6.11 \mathrm{hPa}$ assuming saturation (Brock and Arnold, 2000). Under sub-zero conditions, we assume saturation of the surface layer. The surface water vapour pressure therefore depends only on the surface temperature and was calculated according to Eqn (2).

Finally, the wind speed was distributed using the hourly observed gradients between the pairs of AWS. On the west side, the gradients were taken from GT and HSNO and on the eastern side from GO and HSO. This approach has also been used by Fyffe and others (2014) on alpine glaciers. However, due to the uncertainties of this approach (as wind speed is also related to local topographic characteristics), we used a constant wind speed to check the sensitivity of the SEB model to this variable. Here, the wind speed measurements at the mid-elevation AWS, HSNO and HSO (Table 1), were assumed representative of the west side and the east side, respectively. Table 2 shows a summary of the methods to distribute meteorological variables including the time step and related references.

\subsection{SEB model}

A distributed SEB model was applied using the distributed meteorological fields (section 2.2) based on the AWS data collected between 1 October 2015 and 31 June 2016 (Table 1). The time step used in the SEB model was hourly, even though the approach to surface temperature estimation (Eqn (3)) is recommended for daily data (Raleigh and others, 2013). The energy available for melting, $Q_{m}$ $\left(\mathrm{W} \mathrm{m}^{-2}\right)$, was determined following the equation:

$$
Q_{\mathrm{m}}=(1-\alpha) S_{\text {in }}+L_{\text {in }}+L_{\text {out }}+Q_{\mathrm{h}}+Q_{\mathrm{l}}+Q_{\mathrm{r}} \text {, }
$$

where $S_{\text {in }}$ and $\alpha$ are incoming shortwave radiation and albedo, $L_{\text {in }}$ and $L_{\text {out }}$ are incoming and outgoing longwave radiation and $Q_{\mathrm{h}}$ and $Q_{1}$ are the turbulent fluxes of sensible and latent heat, respectively. $Q_{\mathrm{r}}$ is the sensible heat brought to the surface by rain. The conductive heat flux was considered negligible due to the predominantly positive air temperatures and the temperate conditions of the glacier surface (e.g. Schneider and others, 2007; Gillett and Cullen, 2010; Schwikowski and others, 2013).

After computing the energy available for melt, the surface ablation was calculated as the sum of the surface melt and sublimation. Melt was assumed to occur only when the glacier surface was at $0^{\circ} \mathrm{C}$ and $Q_{\mathrm{m}}$ was positive. The melt rate $(M)$ was calculated as follows:

$$
M=\frac{Q_{\mathrm{m}}}{L_{\mathrm{m}} \rho_{\mathrm{w}}},
$$

where $L_{\mathrm{m}}$ is the latent heat of fusion and $\rho_{\mathrm{w}}$ is the water density $\left(1000 \mathrm{~kg} \mathrm{~m}^{-3}\right)$.
The sublimation rate $(S)$ was calculated as follows (Cuffey and Paterson, 2010):

$$
S=\frac{Q_{\mathrm{l}}}{L_{\mathrm{s}} \rho_{\mathrm{w}}}
$$

where $L_{\mathrm{s}}$ is the latent heat of sublimation. The negative values of latent heat fluxes $\left(Q_{1}\right)$ under negative surface temperature correspond to sublimation (Ayala and others, 2017).

\subsection{Shortwave and longwave radiation fluxes}

Distributed global radiation was derived using a radiation model in a GIS environment (Fu and Rich, 2002) and using TanDEM-X digital elevation data. Global radiation comprises direct and diffuse solar radiation and was computed under a clear-sky assumption with bulk atmospheric transmissivity equal to 1 , to represent the potential clear sky shortwave radiation $S_{\text {in,pot }}$ at each gridpoint. The potential clear-sky shortwave radiation was corrected using the bulk atmospheric transmissivity $\left(\tau_{\text {atm }}\right)$ derived from the relationship between the potential and the observed shortwave radiation at the location of each AWS (Sicart and others, 2010). In the cases when observed values are higher than potential values (probably due to instrument malfunction), atmospheric transmissivity was assumed to be equal to 1 . The bulk atmospheric transmissivity was spatially distributed $\left(\tau_{\text {atm,dis }}\right)$ as a linear relationship with elevation on each side of the SPI (e.g. see data presented in Fig. S2). Hence, the incoming shortwave radiation at the glacier surface is $\left(S_{\text {in,gla }}\right)$ :

$$
S_{\text {in,gla }}=\tau_{\text {atm,dis }} \cdot S_{\text {in,pot }},
$$

The albedo of the glacier surface was estimated using the model of Oerlemans and Knap (1998). This model assumes that albedo depends on the age of the snow surface and depth. To estimate the snow accumulation on the glacier surface we used the total precipitation data from ERA5-Land $(9 \mathrm{~km})$ (Muñoz-Sabater and others, 2021) resized to $200 \mathrm{~m}$ using a nearest neighbour method. The snow accumulation was estimated using the phase partitioning methods (PPMs) proposed by Weidemann and others (2018) which showed a close fit between modelled and observed accumulation rates, with observations coming from UDGs within the study area and presented in Bravo and others (2019b). The air temperature used to define the partitioning was not bias-corrected as we assumed that the contributing snow mass is formed entirely outside the GBL. In this case, the comparison between ERA5Land derived accumulation and the UDGs (GBL stations; Fig. 1, Table 1) derived accumulation, while not perfect (see Fig. S3), shows a good linear relationship, reaching an $r$ value of 0.73 for the UDG installed at GBL2 (1294 m a.s.l.) and 0.55 for the UDG installed at GBL1 (1415 m a.s.l.). This means that there is a similar inter-daily variability between both datasets. The total accumulation estimated in GBL1 was $0.9 \mathrm{~m}$ w.e. using 
ERA5-Land data and $1.1 \mathrm{~m}$ w.e. using the UDG. This latter value was also reported by Durand and others (2019) at the same location and for a similar period. Then the albedo is estimated using the relationships (Oerlemans and Knap, 1998):

$$
\begin{aligned}
& \alpha_{\mathrm{s}}^{t}=\alpha_{f i}+\left(\alpha_{\mathrm{fr}}-\alpha_{\mathrm{fi}}\right) \cdot \exp ^{-\Delta t / t^{*}}, \\
& \alpha^{t}=\alpha_{\mathrm{s}}^{t}+\left(\alpha_{\text {ice }}-\alpha_{\mathrm{s}}^{t}\right) \cdot \exp ^{-d / d^{*}},
\end{aligned}
$$

where $\alpha^{t}$ corresponds to the global albedo at the surface on a specific day $t$. $\alpha_{\mathrm{s}}^{t}$ corresponds to the snow albedo at the surface on day $t$. The parameters $\alpha_{\mathrm{fr}}$ and $\alpha_{\mathrm{fi}}$ represent fresh snow albedo $(0.85)$ and firn or old snow albedo (0.53), respectively. $\alpha_{\text {ice }}$ represents a specific glacier ice albedo (0.35), while $t^{*}$ corresponds to the timescales that represent the transition of fresh snow albedo to firn (3 days). The term $\Delta t$ refers to days since the last snowfall event. The parameters $d$ and $d^{*}$ correspond to the snow depth (in $\mathrm{m})$, and scale coefficient of snow depth $(0.032 \mathrm{~m})$, respectively.

To validate the surface albedo output estimated by the model, we used albedo values derived from available (e.g. cloud-free) Landsat-8 OLI satellite images during the same period at a spatial resolution of $30 \mathrm{~m}$. Processing of the Landsat imagery is described and explained in the Supplementary material. Overall, the modelled albedo replicated the elevational gradient of the Landsat-8-derived albedo (Fig. 2a,b), but without some of the finer details, partly due to the differences in resolution. The greatest differences were concentrated on the glaciers at mid-elevation on each side of the SPI, probably related to the exact location of the snowline. The albedo from Landsat was also used to define the albedo of the supraglacial moraines observed on the glacier ablation zone of the study area. Hence, the albedo of the supraglacial moraine was obtained from the Landsat- 8 images acquired on 8 March 2016 and was prescribed for each day depending on the snowline elevation. As albedo was computed at daily time step, to coincide with our other hourly data, we assumed this value was constant throughout the day due to its slow evolution.

Incoming longwave radiation $\left(L_{\text {in, gla }}\right)$ was estimated using the Stefan-Boltzmann law (i.e. Mölg and others, 2009; Ayala and others, 2017):

$$
L_{\text {in,gla }}=\varepsilon_{\mathrm{atm}} \cdot \sigma T^{4} \cdot S_{\mathrm{vf}},
$$

where $\sigma$ is the Stefan-Boltzmann constant and $S_{\text {vf }}$ is the sky-view factor calculated (Oke, 1987) with the TanDEM-X digital elevation data. $S_{\mathrm{vf}}$ varied between 1 in the lower slope zones of the plateau and $\sim 0.55$ in the higher slopes. Atmospheric emissivity for all-sky conditions $\left(\varepsilon_{\mathrm{atm}}\right)$ was calculated as the product of clear-sky emissivity $\left(\varepsilon_{\text {atm,clear }}\right)$ and the cloud factor $\left(F_{\mathrm{cl}}\right)$. The cloud factor was obtained as the ratio of the observed and the clear-sky incoming longwave radiation at the location of two representative midelevation AWS, HSNO on the west side and HSO on the east side. In this case, it was assumed that the cloud factor is representative of the total area of the glaciers on each side. Meanwhile, the clear-sky emissivity was estimated using the spatially distributed fields of air temperature $(\mathrm{K})$ and the water vapour pressure (hPa) using the Brutsaert (1975) expression:

$$
\varepsilon_{\text {atm, clear }}=P_{1}\left(e / T_{\mathrm{a}}\right)^{1 / P^{2}},
$$

where $P_{1}=1.24$ and $P_{2}=7$.

The outgoing longwave radiation was calculated using the distributed field of surface temperature and assuming a surface emissivity equal to 1 in the Stefan-Boltzmann law.

\subsection{Sensible, latent and rainfall heat fluxes}

The turbulent heat fluxes were calculated using the bulk approach (Cuffey and Paterson, 2010). In the case of the sensible heat flux:

$$
Q_{\mathrm{h}}=\rho_{\mathrm{a}} c_{\mathrm{a}} C^{*} u\left[T_{\mathrm{a}}-T_{\mathrm{s}}\right]\left(\Phi_{\mathrm{m}} \Phi_{\mathrm{h}}\right)^{-1}
$$

where $u$ is the wind speed in $\mathrm{m} \mathrm{s}^{-1}, T_{\mathrm{a}}$ is the air temperature in $\mathrm{K}$ and $T_{\mathrm{s}}$ is the glacier surface temperature. $C^{*}$ is a dimensionless transfer coefficient, which is a function of the surface aerodynamic roughness $\left(z_{0}\right)$ :

$$
C^{*}=\frac{k^{2}}{\ln ^{2}\left(z / z_{0}\right)}
$$

where $z$ is the height above the surface of the $T_{\mathrm{a}}$ and $u$ measurements $(2 \mathrm{~m})$ and $k$ is the von Kárman's constant (0.4). Due to the absence of microtopographic measurements, $z_{0}$ was prescribed according to the albedo using values taken from Brock and others (2006) (Table S1). This is a general approximation to estimate the surface roughness as, for instance, wind speed is not considered, while in the aerodynamic method it is used for fitting the wind profile to determine $z_{0}$ (Chambers and others, 2020). However, it has been suggested that surface roughness also affects surface albedo, especially on snow surfaces (Manninen and others, 2016).

$\rho_{\mathrm{a}}$ is the density of air, which depends on atmospheric pressure $P($ in $\mathrm{Pa})$ :

$$
\rho_{\mathrm{a}}=\rho_{\mathrm{a}}^{0} \frac{P}{P_{0}},
$$

where $\rho_{\mathrm{a}}^{0}\left(1.29 \mathrm{~kg} \mathrm{~m}^{-3}\right)$ is the density at standard pressure $P_{0}$ $(101300 \mathrm{~Pa})$. Finally, $c_{\mathrm{a}}$ is the specific heat of air at constant pressure $\left(\mathrm{J} \mathrm{kg}^{-1} \mathrm{~K}^{-1}\right)$ calculated as follows (Brock and Arnold, 2000):

$$
c_{\mathrm{a}}=1004.67\left(1+0.84\left(0.622\left(\frac{e}{P}\right)\right)\right),
$$

The latent heat flux $Q_{1}$ is

$$
Q_{1}=\frac{0.622 \rho_{\mathrm{a}} L_{\mathrm{v} / \mathrm{s}} C^{*} u\left[e_{\mathrm{a}}-e_{\mathrm{s}}\right]}{P}\left(\Phi_{\mathrm{m}} \Phi_{\mathrm{h}}\right)^{-1}
$$

where $e_{\mathrm{a}}$ is the water vapour pressure in the air, $e_{\mathrm{s}}$ is the water vapour pressure at the glacier surface (Brock and Arnold, 2000) and both were estimated using Eqns (1) and (2) but at distributed scale. $L_{\mathrm{v} / \mathrm{s}}$ is the latent heat of vaporisation or sublimation, depending on whether the surface temperature is at melting point $\left(0^{\circ} \mathrm{C}\right)$ or below the melting point $\left(<0^{\circ} \mathrm{C}\right)$, respectively.

Stability corrections were applied to turbulent fluxes using the bulk Richardson number $\left(R i_{\mathrm{b}}\right)$, which is used to describe the stability of the surface layer (Oke, 1987):

$$
R i_{\mathrm{b}}=\frac{g\left(T-T_{\mathrm{s}}\right)\left(z-z_{0}\right)}{T u^{2}}
$$

where $g$ is the acceleration due to gravity.

For $R i_{\mathrm{b}}$ positive (stable)

$$
\begin{aligned}
\left(\Phi_{\mathrm{m}} \Phi_{\mathrm{h}}\right)^{-1} & =\left(\Phi_{\mathrm{m}} \Phi_{\mathrm{v}}\right)^{-1} \\
& =\left(1-5 R i_{\mathrm{b}}\right)^{2},
\end{aligned}
$$


a Observed Albedo Landsat 8-January-2016

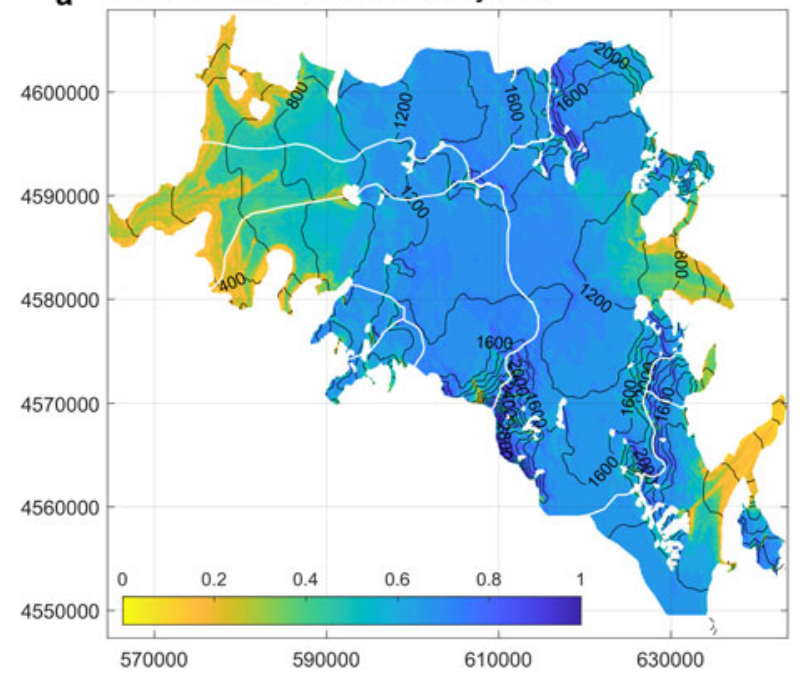

b Modelled Albedo 8-January-2016

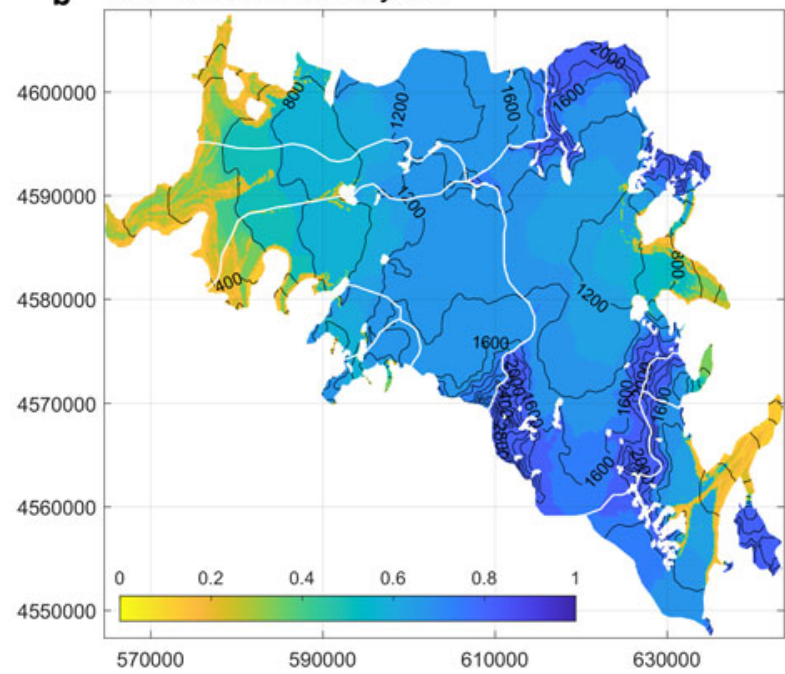

Fig. 2. Comparison of the observed albedo using Landsat-8 satellite images (a) and modelled albedo using Oerlemans and Knap (1998) approach (b). Albedo values on supraglacial moraine in (b) were prescribed.

For $R i_{\mathrm{b}}$ negative (unstable)

$$
\begin{aligned}
\left(\Phi_{\mathrm{m}} \Phi_{\mathrm{h}}\right)^{-1} & =\left(\Phi_{\mathrm{m}} \Phi_{\mathrm{v}}\right)^{-1} \\
& =\left(1-16 R i_{b}\right)^{0.75},
\end{aligned}
$$

The rain heat flux $\left(Q_{\mathrm{r}}\right)$ is a function of the rainfall rate intensity $\left(R, \mathrm{~m} \mathrm{~s}^{-1}\right)$ and the rain temperature $\left(T_{\mathrm{r}}\right)$ is assumed to be equal to the air temperature (Hock and Holmgren, 2005; Gillett and Cullen, 2010):

$$
Q_{\mathrm{r}}=\rho_{\mathrm{w}} c_{\mathrm{w}} R\left[T_{\mathrm{r}}-T_{\mathrm{s}}\right]
$$

where $\rho_{\mathrm{w}}$ is the density of water and $c_{\mathrm{w}}$ is the specific heat of water $\left(4180 \mathrm{~J} \mathrm{~kg}^{-1} \mathrm{~K}^{-1}\right)$. The rainfall intensity was obtained from the total precipitation ERA5-Land dataset at a daily time step. The rainfall was obtained from the total precipitation using four PPMs (Koppes and others, 2011; Ding and others, 2014; Schaefer and others, 2015; Weidemann and others, 2018) as explained in Bravo and others (2019b).

\section{Results}

\subsection{Meteorological conditions: observations and distribution}

At comparable elevations, off-glacier air temperatures were higher in the east compared to the west, as the mean value of HSO $(1234 \mathrm{~m}$ a.s.l.) was similar to HSNO (1040 $\mathrm{m}$ a.s.l.), although the former was located at a higher elevation (Fig. 3a). As expected, distributed on-glacier air temperature and distributed glacier surface temperature were lower on the east side compared to the west side due to a strong cooling effect, which has been observed in a previous study (Bravo and others, 2019a). In the ablation zones, mean glacier surface temperatures were close to $0^{\circ} \mathrm{C}$ (and surface water vapour pressure close to $6.11 \mathrm{hPa}$; Figs $4 \mathrm{~b}, \mathrm{~d}$ ). Lo Vecchio and others (2019) estimated colder surface temperatures using MODIS products in the lower part of O'Higgins Glacier, reaching -2.4 to $-5.2^{\circ} \mathrm{C}$ between 500 and $1300 \mathrm{~m}$ a.s.l., while our estimation for the same elevation range was between -0.1 and $-1.7^{\circ} \mathrm{C}$. Western-facing glaciers comprised of a larger elevation range below the $0^{\circ} \mathrm{C}$ isotherm (Fig. 4a).

Relative humidity shows different behaviours between each side of the SPI (Figs 3b, 4c). On the west side, the relative humidity shows low-spatial variability as the observed mean values tend to be similar irrespective of elevation (Fig. 3b). On the eastern side, lower mean values were observed and a strong gradient between HSO (mean of $78 \%$ during the nine months period) and GO (mean of 57\%) was determined (Fig. 3b). Following this pattern, distributed relative humidity and surface water vapour pressure (Figs 4c, d) show, overall, drier conditions in the east in comparison with the west.

The wind speed (Figs 3c, 4f) increases with elevation on the west side while the maximum values were observed at mid elevations of the eastern side (HSO), reaching a mean of $9 \mathrm{~m} \mathrm{~s}^{-1}$ but with maximum hourly means reaching $25-30 \mathrm{~m} \mathrm{~s}^{-1}$ at this location. Lower mean values were observed at the lower elevations on the western side. Distributed wind speed reached a maximum spatial mean of $\sim 22 \mathrm{~m} \mathrm{~s}^{-1}$ (Fig. 4f) at the highest elevation of the study area (Volcán Lautaro $\sim 3600 \mathrm{~m}$ a.s.l.). The wind speeds, we estimated here (after using the observed gradient), are comparable to those determined by Lenaerts and others (2014) using the regional atmospheric climate model RACMO2 at a level of $700 \mathrm{hPa}$.

\subsection{SEB fluxes}

The observed incoming shortwave radiation showed differences on either side of the divide (Fig. 3e). Lower values were observed on the western side, especially at GT and HSNO. On the ice divide (HSG), the incoming shortwave radiation showed the maximum values, followed by the eastern side AWS (HSO, GO). Higher values were due to the period between December 2015 and April 2016 being characterised by positive solar radiation anomalies increasing the insolation by $\sim 20 \%$ compared to the annual climatology (Garreaud, 2018). However, we cannot discard some outlier values due to erroneous measurements. The observed incoming longwave radiation values were larger in the west than in the east; HSNO in the west $(1040 \mathrm{~m}$ a.s.l.) and GO in the east $(310 \mathrm{~m}$ a.s.l.) showed similar values despite the elevation differences. The differences in magnitude that are evident in incoming shortwave and longwave radiation values either side of the divide can be attributed to differences in the cloud cover, being more persistent on the west side.

The distributed spatial and temporal mean SEB fluxes modelled for the period between October 2015 and June 2016 per elevation range until $2000 \mathrm{~m}$ a.s.l. are shown in Figure 5, while the maps of the distributed mean fluxes over the study period are presented in Figure 6. Overall, across all the glacier surfaces, net shortwave radiation, sensible heat flux and rain heat 

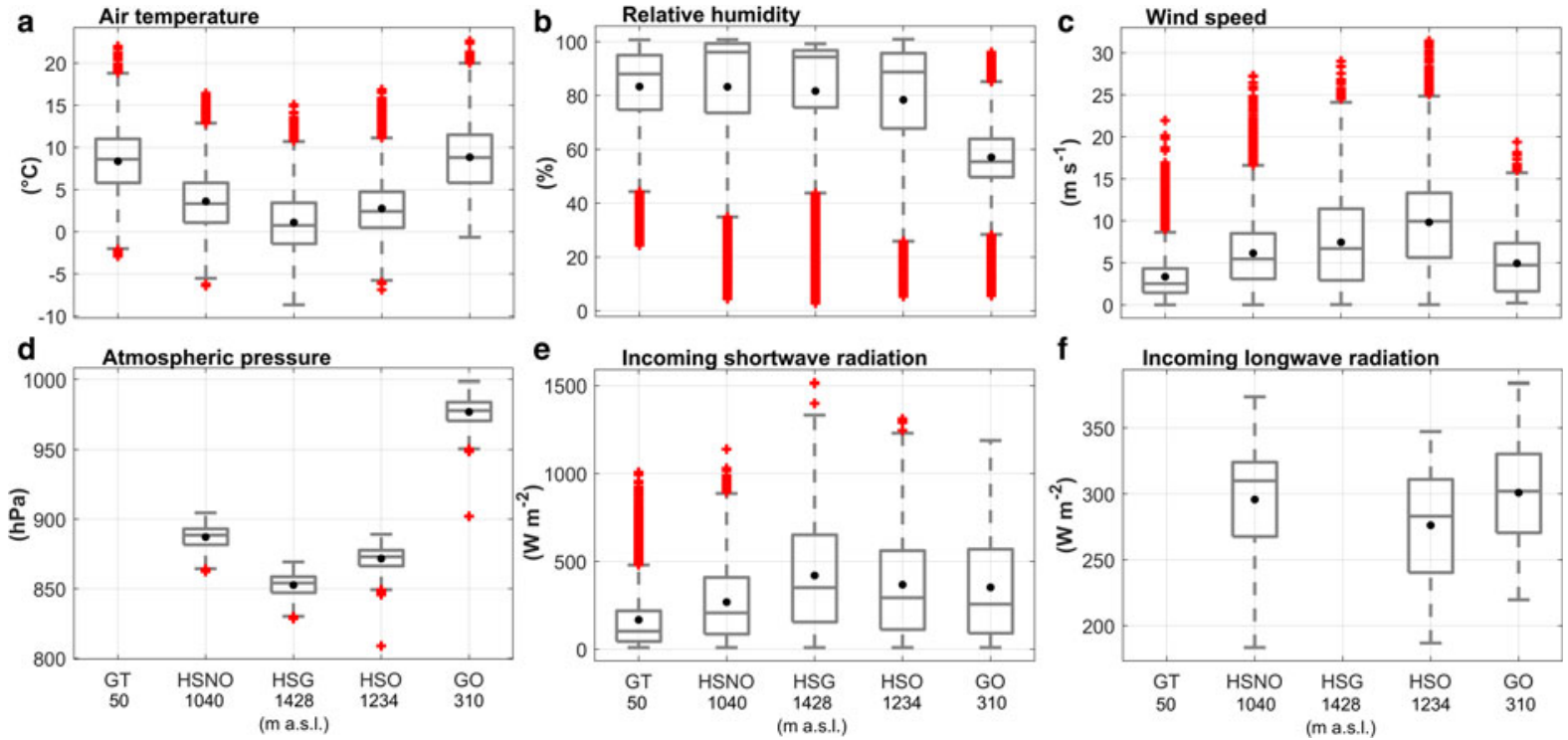

Fig. 3. Boxplot summaries of the hourly observed meteorological variables in the SPI during the period October 2015 to June 2016 . Data used in the incoming shortwave radiation boxplots (e) correspond to observed hourly values over $5 \mathrm{~W} \mathrm{~m}^{-2}$. Upper and lower box limits are the 75 and $25 \%$ quartiles, the horizontal line is the median, the filled black circle is the mean, whiskers are extreme values not considered outliers and red crosses are outlying values (more than 1.5 times the interquartile range away from the bottom or top of the box).
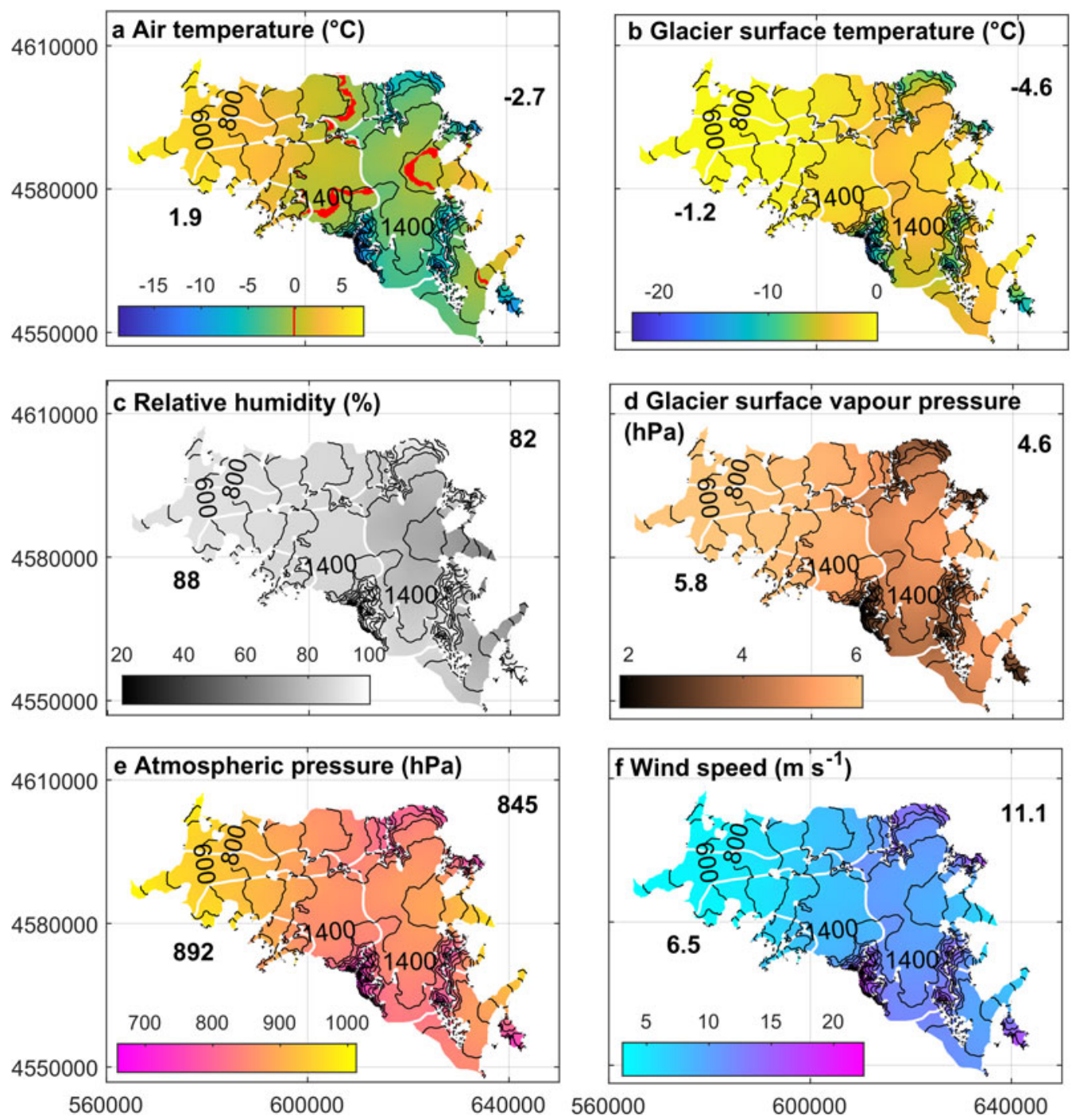

Fig. 4. Spatially distributed mean values of the meteorological variables during the period October 2015 to June 2016 . Numbers shown in each variable map represent mean glacier-wide values for each side of the icefield. White lines are the glacier divide and black lines are contours at an interval of $200 \mathrm{~m}$. Coordinates are in m, UTM18-S, WGS-1984. 

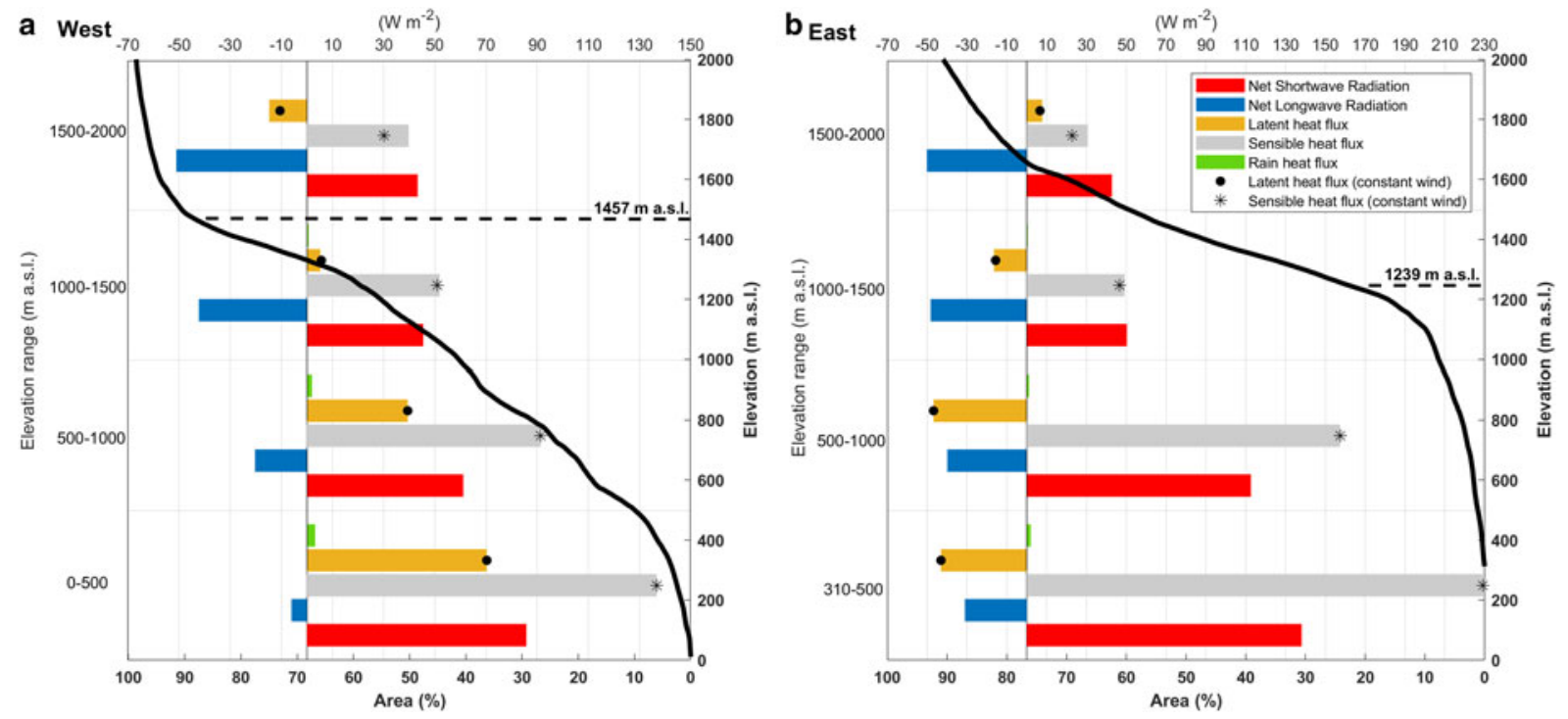

Fig. 5. Mean values of the energy-balance fluxes per elevation range and margin of the SPI during the period between October 2015 and June 2016 , focused on the elevations where most of the melt occurs and most of the glacier area is concentrated: (a) west and (b) east. For reference, hypsometric curves (black continuous line) estimated using the TanDEM-X data with the accumulated area in the bottom axis and the elevations in the left axis are shown along with the mean elevation of the isotherm $0^{\circ} \mathrm{C}$ (dashed line).

flux were positive, which means that they were a source of energy available for surface melt and heating.

Sensible heat flux was, overall, the dominant source of energy on both sides, even assuming constant wind speed (Fig. 5). However, at elevations between 1000 and $2500 \mathrm{~m}$ a.s.l. in the west and above $1500 \mathrm{~m}$ a.s.l. in the east, the absolute value was similar to the net shortwave and longwave radiation. The sensible heat flux showed larger positive values on the lower elevations of the east side. This area was characterised by a strong temperature gradient between the glacier surface (fixed at $0^{\circ} \mathrm{C}$ for most of the period; Fig. $4 \mathrm{~b})$ and the air $\left(4-5^{\circ} \mathrm{C}\right.$; Fig. $\left.4 \mathrm{a}\right)$, and relatively strong winds. However, the maximum values correspond to the supraglacial moraine areas, where we assumed highest surface roughness; thus, the value depends on the fixed surface roughness. For instance, on the ice surface areas in the frontal section, the mean sensible heat flux reached a value of $\sim 190 \mathrm{~W} \mathrm{~m}^{-2}$ while on the supraglacial moraine surfaces it reached a mean value of $\sim 220 \mathrm{~W} \mathrm{~m}^{-2}$ (Fig. $6 \mathrm{~d}$ ). This $30 \mathrm{~W} \mathrm{~m}^{-2}$ of enhanced sensible heat corresponds to a difference in surface roughness of only $0.006 \mathrm{~m}$ in the sensible heat flux computation.

The net shortwave radiation was the second highest flux at the lower elevations $(<1000 \mathrm{~m}$ a.s.l.), but the magnitude on the east side, where clear skies prevail, in comparison with the west side, was higher by $\sim 40-50 \mathrm{~W} \mathrm{~m}^{-2}$. Due to a relatively high albedo in the east (mean 0.77) compared to the west $(0.67)$, the spatial mean net shortwave radiation was almost identical between both sides; $54 \mathrm{~W} \mathrm{~m}^{-2}$ to the west and $52 \mathrm{~W} \mathrm{~m}^{-2}$ to the east (Fig. 6). The net shortwave radiation showed a relative maximum in the supraglacial moraine area as a reduction in albedo occurs (Fig. 6a)

Net longwave radiation was negative across almost all the glacier surface, hence removing energy. The exception to this was in the lower elevations of the west side, where near-constant cloud cover and positive temperatures prevailed over the analysed period (Fig. 6b). In terms of spatial mean values (Fig. 5), in the western lower elevations, incoming longwave radiation reached values comparable to the emitted longwave radiation, which most of the time was at $315 \mathrm{~W} \mathrm{~m}^{-2}$ as the glacier surface was at the melting point. Hence, the net longwave radiation was close to zero in this area. At the same elevation on the eastern side, the cloud cover was lower, and less water vapour was in the atmosphere, hence the incoming longwave radiation was predominantly lower than the emitted, as the glacier surface was still close to the melting point most of the time. Above an elevation of $1000 \mathrm{~m}$ a.s.l., the net longwave radiation becomes more negative on both sides, and even becomes the flux with the highest absolute value between 1500 and $2500 \mathrm{~m}$ a.s.l. on the western side.

The latent heat flux (Fig. 6c) demonstrated the largest spatial variability, with positive values estimated on the west side and negative values on the east side consistent with the relatively dry conditions and strong wind speed on the east side. The latent heat flux was therefore a sink of energy until $1500 \mathrm{~m}$ a.s.l. on the eastern side, whereas on the western side it was a source of energy up to $\sim 1500 \mathrm{~m}$ a.s.l. (Fig. 5).

The rain heat flux showed maximum values on the west side where more rainfall occurs, but reached a spatial and temporal mean of just $4-5 \mathrm{~W} \mathrm{~m}^{-2}$ with daily maxima $\sim 11 \mathrm{~W} \mathrm{~m}^{-2}$.

As might be expected, the maximum values $\left(>300 \mathrm{~W} \mathrm{~m}^{-2}\right)$ of energy available for melt/heating were at lower elevations on each side, decreasing to values lower than $100 \mathrm{~W} \mathrm{~m}^{-2}$ in most of the plateau area. Glacier-wide mean values were considerably higher in the west $\left(115 \mathrm{~W} \mathrm{~m}^{-2}\right)$ compared to the east $\left(50 \mathrm{~W} \mathrm{~m}^{-2}\right)$ (Fig. 6f).

\subsection{Surface ablation}

The computed ablation shows good agreement with the magnitude of the ablation estimated with the GBL stations (Fig. S4), but with some differences in the variability and the magnitude of some events. Unfortunately, these sensors only captured data for 3 months in the case of GBL1 and 2 months in the case of GBL2. The surface melt was the dominant ablation component over most of the glacier area on both sides (Fig. 7). Comparatively, the magnitude was higher in the west, especially in the range between 1000 and $2000 \mathrm{~m}$ a.s.l. where mean differences were in the range of $1-4 \mathrm{~m}$ w.e. when compared to the east side. On the eastern side, between 1000 and $1500 \mathrm{~m}$ a.s.l., melt was approximately half of the melt on the west side. In this elevation range, the eastern side melt decreased sharply 

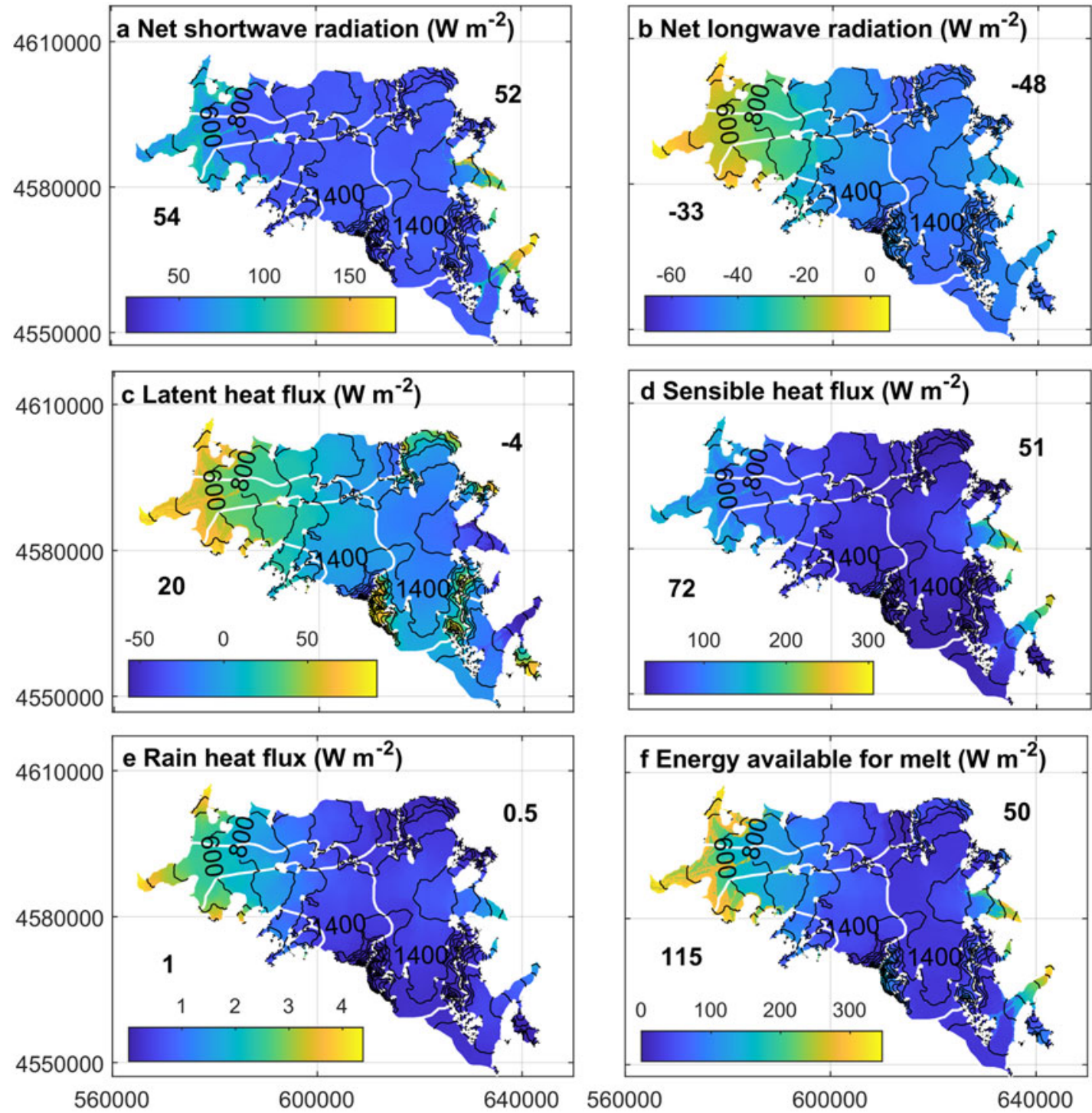

Fig. 6. Distributed mean values of the energy-balance fluxes estimated over the period October 2015-June 2016. Values are the glacier-wide mean for each flux. White lines are the glacier divide and black lines are contours at an interval of $200 \mathrm{~m}$. Coordinates are in m, UTM18-S, WGS-1984.
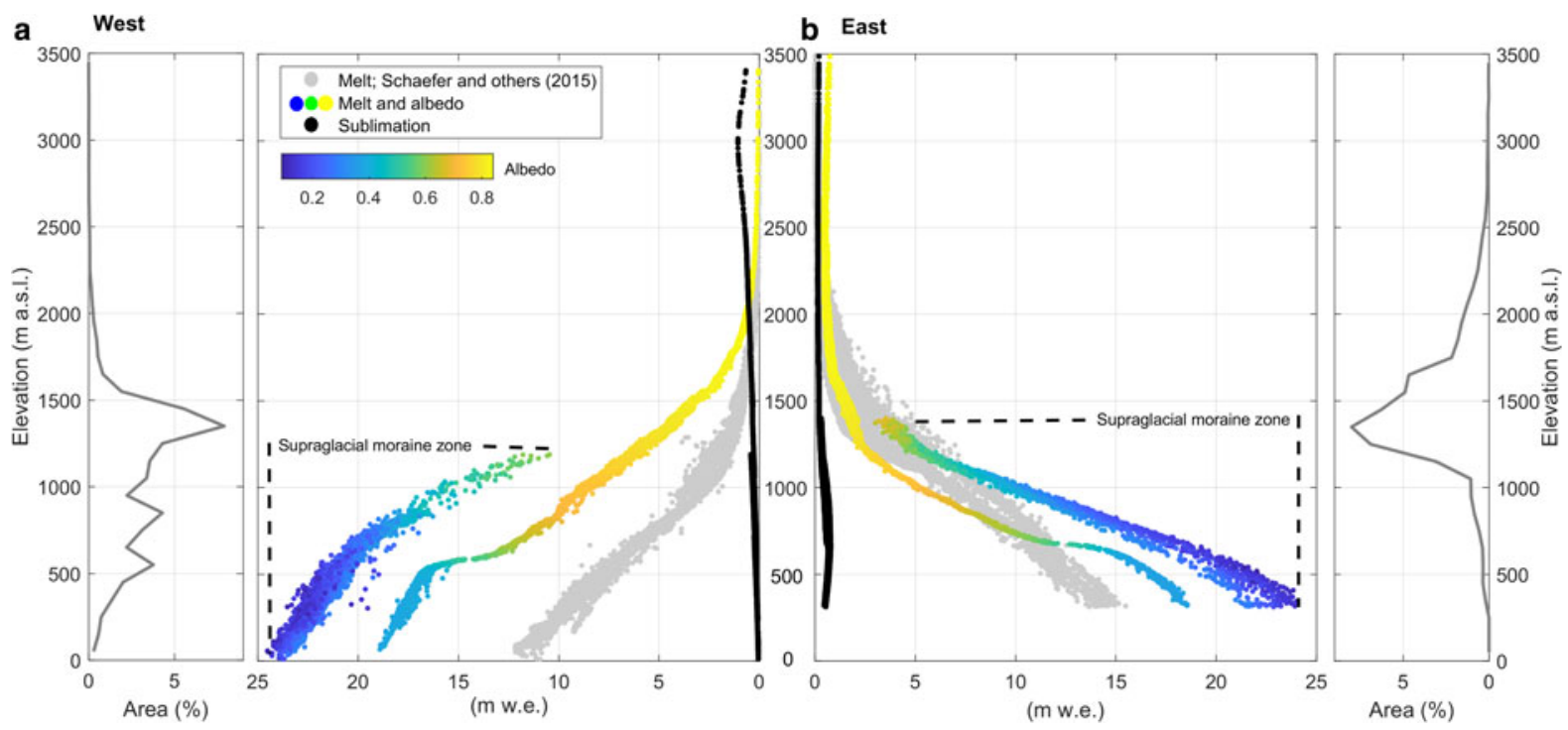

Fig. 7. Total modelled melt and sublimation over the whole period. (a) West, melt and sublimation (black circles) vs elevation. The colour of each melt point denotes the albedo used in the SEB model and the grey line is the glacier hypsometry with the area per $100 \mathrm{~m}$ bin. (b) Same as (a) but for the eastern margin glaciers. Grey points correspond to the melt computed by Schaefer and others (2015) and represent the mean for the period 1975-2011. Zones of supraglacial moraine where albedo reduction and enhanced melt occurs are indicated on both sides. 
to $<5 \mathrm{~m}$ w.e. above $1000 \mathrm{~m}$ a.s.l., hence, most of the melt on eastern side glaciers was observed around their termini. On the western side, surface melt $>10$ m w.e. was observed up to an elevation of $\sim 900 \mathrm{~m}$ a.s.l.

On both sides, and due to a local reduction in surface albedo, the maximum melt occurred at supraglacial moraine areas on the lower sections (marked curves in Fig. 7) reaching maximum values on the order of $24 \mathrm{~m}$ w.e. Melt in supraglacial moraine areas was $2-5 \mathrm{~m}$ w.e. higher than melt in debris-free areas at the same elevations (Fig. 7). At the glacier scale, melt reached 9.3 $\mathrm{m}$ w.e. $(8.5 \mathrm{~m}$ w.e.) on the west side and $2.9 \mathrm{~m}$ w.e. $(2.4 \mathrm{~m}$ w.e.) on the east side depending on the inclusion (or not) of the moraine albedo parameterisation (Fig. 2). Hence, the impact of the moraine albedo parameterisation was relatively higher on the eastern side as melt increased by $17 \%$, while in the west, it increased by $9 \%$.

The impact of using constant wind speed, obtained from the mid-elevation AWS at each side, is minimal on the surface ablation. The glacier-wide surface ablation on the western side was reduced by $0.4 \%$, while on the eastern side it was reduced by $2 \%$.

The percentage of glacier-wide sublimation compared to net ablation in the west was $1.9 \%$ and in the east it was $5.4 \%$. Spatial differences were observed when comparing both sides. On the west side, sublimation was the main component of the surface ablation at elevations over $2000 \mathrm{~m}$ a.s.l., which corresponds to an area of $2 \%$ (Fig. 7a). Meanwhile, eastern-facing glaciers showed maximum values on their lower sections due to the relatively dry air on the east side while the surface is close to saturation. In contrast, western side glaciers are under strong maritime climate conditions with near-saturated air, and hence sublimation is much lower.

\section{Discussion}

\subsection{Energy-balance fluxes: uncertainties and comparison with previous studies}

Elevation gradients are commonly applied for distributing meteorological variables in glacier mass-balance modelling studies operating at different spatial and temporal scales (Braun and Hock, 2004; Fyffe and others, 2014; Mölg and others, 2020). However, inherent limitations and uncertainties exist with this approach as well as with the SEB model used in this study. Overall, the uncertainties increase with elevation as the highest AWS in our network was located at $1428 \mathrm{~m}$ a.s.l. Above this elevation, the representativeness of the observations and the distribution methods decrease.

Computed values of the turbulent fluxes depend on several assumptions made here. A key assumption is that under sub-zero conditions the snow surface is saturated (e.g. Raleigh and others, 2013) and hence the surface water vapour pressure depends only on surface temperature. On the eastern side, this assumption generates high positive values in the latent heat flux, creating a discontinuity with the conditions on the western side. The alternative approach, which is to attempt to compute surface water vapour pressure under subsaturated conditions is, however, also of high uncertainty (Shea and Moore, 2010). Observations made elsewhere indicate that under sub-zero conditions the air near a snow/ice surface may indeed be unsaturated (Schmidt, 1982; Box and Steffen, 2001). Consequently, the latent heat flux calculated at higher elevations and under predominantly sub-zero conditions, must be taken with caution.

An important limitation is the assumption that a discrete number of meteorological observations are sufficient to fully characterise the micrometeorological conditions (e.g. Sauter and Galos, 2016; Bonekamp and others, 2020). For instance, wind speed is known to be highly variable over glacierised surfaces (Sauter and Galos, 2016) and bulk values are likely therefore to mask much of the detail. Indeed, this has great impact on sensible heat flux estimations on mountain glaciers (Sauter and Galos, 2016). Similar consideration can be given here to the other observed meteorological variables, particularly those with greater spatial variability that depends, for instance, on cloud cover. For instance, bias in local cloud cover (e.g. topographic effects) could be extended to the whole glacier area.

In order to analyse the sensitivity of the SEB modelled to wind speed, our results were presented using two wind speed parametrisations. In term of sensible heat flux, differences up to $180 \mathrm{~W} \mathrm{~m}^{-2}$ were estimated, however, in terms of melt, uncertainty related to wind speed was minimal as the highest differences in the magnitude of sensible heat flux were in areas where the surface air temperature was constantly below $0^{\circ} \mathrm{C}$ and/or represented a small fraction of the total area. In the former case, this means that the available energy was heating the snow surface and no melting occurred.

Another uncertainty is related to the type of surface and the turbulent fluxes. Nicholson and Stiperski (2020) have previously shown that turbulent heat fluxes over both thinner debris and debris-free areas can be positive and of similar magnitude, except under sunny conditions where larger differences $\left(>100 \mathrm{~W} \mathrm{~m}^{-2}\right)$ in the fluxes between both surface-types were observed. This introduces some uncertainties into our estimations of turbulent fluxes, especially over supraglacial moraines in the east (e.g. Chico Glacier; Fig. 1), where sunny conditions were more frequent. In order to better represent the influence of the debris on turbulent fluxes, temporally and spatially comprehensive surface temperature measurements on supraglacial debris are needed, but these do not yet exist, at least in the region of study.

In the context of previous studies, quantification of SEB fluxes for SPI glaciers at different spatial and temporal scales is limited to a few cases (Table 3). A direct comparison of values is difficult, bearing in mind the inevitable differences in spatial and temporal scales of analysis. Nevertheless, as might be expected, net shortwave radiation is consistently shown to be a source of energy. In the case of net longwave radiation, all previous research agrees that it is a sink of energy as negative values prevail over glaciers (Table 3; Weidemann and others, 2018; Schaefer and others, 2020). In our case, just a small areal fraction on the frontal section on the west side showed slightly positive values (Fig. 6b).

Overall, most of the previous research agrees on the importance of sensible heat flux as a control on Patagonian glacier melt. The dominance of the sensible heat flux is a common characteristic of glaciers under maritime conditions (e.g. Schneider and others, 2007). Over ice and at the point-scale on Tyndall Glacier, Takeuchi and others (1999) estimated that sensible heat flux is $\sim 45 \%$ of the total energy available for melt, while Schaefer and others (2020) estimated that sensible heat flux was the second highest flux after net shortwave radiation. Our calculated values were higher than those previously estimated at a glacier-wide scale, meaning that it was the main source of energy on the western side and of the same magnitude as the net shortwave radiation on the eastern side during the analysed period.

For latent heat flux, disagreement exists in the literature around its magnitude and the role that it plays in the SEB. Both Takeuchi and others (1999) and Schaefer and others (2020) estimated positive values on Tyndall Glacier. Weidemann and others (2018) estimated a mean glacier-wide negative value on Tyndall Glacier as well as over Grey Glacier (Table 3). Our calculations show that latent heat was the most spatially variable flux in terms of its role in the SEB. At lower elevations (0-1500 $\mathrm{m}$ a.s.l.) on the west side it is a source of energy, while above this elevation on the west side, as well as at elevations below $1500 \mathrm{~m}$ a.s.l. on the east side, it was a sink of energy. This 
Table 3. Compilation of previous estimates of energy-balance fluxes in SPI glaciers, at point-scale and distributed

\begin{tabular}{|c|c|c|c|c|c|c|}
\hline Reference & Glacier/Elevation & Period & $\begin{array}{l}\text { Sensible } \\
\text { heat flux } \\
\mathrm{W} \mathrm{m}^{-2}\end{array}$ & $\begin{array}{l}\text { Latent } \\
\text { heat flux } \\
\mathrm{W} \mathrm{m}^{-2}\end{array}$ & $\begin{array}{l}\text { Net shortwave } \\
\text { radiation } \\
\mathrm{W} \mathrm{m}^{-2}\end{array}$ & $\begin{array}{l}\text { Net longwave } \\
\text { radiation } \\
\mathrm{W} \mathrm{m}^{-2}\end{array}$ \\
\hline \multicolumn{7}{|l|}{ Point-scale, AWS: } \\
\hline \multirow[t]{2}{*}{ Takeuchi and others $(1995,1999)$} & Moreno/330 m a.s.l. & 12-27 November 1993 & 126 & -9 & \multicolumn{2}{|c|}{$138^{\mathrm{a}}$} \\
\hline & Tyndall/700 m a.s.l. & 9-17 December 1993 & 111 & 19 & & $36^{\mathrm{a}}$ \\
\hline \multirow[t]{2}{*}{ Schaefer and others $(2020)^{b}$} & Tyndall/608 m a.s.l. & 1 January-31 March 2015 & $65 / 52 / 70$ & 09/05/2009 & $94 / 92 / 132$ & $-14 /-30 /-22$ \\
\hline & & 1 January-31 March 2016 & $76 / 55 / 75$ & 09/05/2008 & $110 / 109 / 135$ & $-13 /-29 /-21$ \\
\hline \multicolumn{7}{|c|}{ Glacier-wide, observations and/or reanalysis climate data: } \\
\hline \multirow[t]{2}{*}{ Weidemann and others (2018) } & Grey & 2000-2016 & 11 & -9 & 39 & -9 \\
\hline & Tyndall & & 16 & -7 & 45 & -18 \\
\hline \multirow[t]{2}{*}{ This study } & West (Greve, Tempano, Occidental) & October 2015-June 2016 & 72 & 20 & 54 & -33 \\
\hline & East (Chico, O’Higgins) & & 51 & -4 & 52 & -48 \\
\hline
\end{tabular}

${ }^{\mathrm{a}}$ Net radiation.

${ }^{\mathrm{b}}$ Schaefer and others (2020) estimated the SEB fluxes using three models.

variability was also temporal (not shown), as during the austral autumn of 2016 the latent heat flux was mostly negative on the west side, meaning that the water vapour pressure gradient was negative. This is a direct consequence of the severe drought detected in western Patagonia during this season (Garreaud, 2018) where anomalously low moisture transport from the Pacific Ocean to the western flank of Patagonia led to relatively lower water vapour pressure in the air compared to the glacier surface. Hence, the temporal and spatial variabilities of the latent heat flux observed in our study, as well as in previous studies, are explained by this flux depending on the air water vapour pressure, which in turn depends on synoptic conditions that define the advection of water vapour over glacier areas.

Additionally, the differences in turbulent fluxes can be related to the characteristics of each glacier. For instance, the fetch length (i.e. the upwind distance over which the conditions affect the observed conditions at a point) of O'Higgins Glacier $(\sim 30 \mathrm{~km})$ differs markedly when compared to Grey and Tyndall glaciers $(\sim 20 \mathrm{~km})$. This could strengthen the intensity of the katabatic wind (Ayala and others, 2015), increasing the cooling effect and the dryness of a descending air parcel over the glacier surface, generating differences between neighbouring glaciers.

\subsection{Drivers of surface ablation}

The relative importance of each SEB flux varied depending on aspect and elevation and even changes in its sign along the transect were found in the case of the latent heat flux (Figs 5, 6c). This spatial pattern was related to the meteorological differences between each side of the divide, forced mainly by the orographic effect and its feedbacks.

In the case of the incoming shortwave radiation, larger differences between clear-sky and overcast conditions exist especially on the west side, but due to albedo differences, net values were similar between both sides. For incoming longwave radiation, the differences in the magnitude between both margins were lower in comparison with the other SEB fluxes, despite differences in cloud cover, probably as relatively warmer off-glacier conditions to the east increase the incoming longwave radiation. This, along with the near-constant surface glacier temperature at $0^{\circ} \mathrm{C}$ that determines the emitted longwave radiation, leads to net longwave radiation being the most spatially homogeneous SEB flux in our study area, showing values between -30 and $-60 \mathrm{~W} \mathrm{~m}^{-2}$, except for below $1000 \mathrm{~m}$ a.s.l. on the west side, where values drop to below $-10 \mathrm{~W} \mathrm{~m}^{-2}$.

Spatial differences were evident in terms of magnitude of the sensible heat flux, reaching maxima where wind speed was higher. On the western side, the maxima have been suggested to be a result of exposure to the dominant westerlies (e.g. Takeuchi and others, 1999). Probably, the occurrence of katabatic winds as well as föhn events (e.g. Ohata and others, 1985; Takeuchi and others, 1995) determines a maximum relative wind speed at mid to lower elevations ( $<1000 \mathrm{~m}$ a.s.l.) on the eastern side. Sensible heat flux mean values between 160 and $230 \mathrm{~W} \mathrm{~m}^{-2}$ were found here (Fig. 5b). This range of values was similar to the values at a higher elevation of the west side, in a zone exposed to the dominant westerlies (Garreaud and others, 2013; Lenaerts and others, 2014). As latent heat flux depends largely on moisture conditions and wind speed, spatial variability of this flux was also found. For instance, negative values on the mid-to-lower elevations to the east in response to a drier atmosphere as well as relatively strong winds were estimated, contrary to the positive values found in the west at similar elevations.

A key element that drives the disparity in surface ablation rates between each side of the divide is the magnitude and role of the latent heat flux and net longwave radiation. The west side below $1500 \mathrm{~m}$ a.s.l. was the only part of our study area where the latent heat flux was a source of energy under predominantly melt conditions (i.e. $T_{\mathrm{a}} \geqslant 0^{\circ} \mathrm{C}$ ), leaving the net longwave radiation as the only sink of energy, but reaching relatively lower values $(-8$ to $-20 \mathrm{~W} \mathrm{~m}^{-2}$ below $1000 \mathrm{~m}$ a.s.l.). Meanwhile, to the east below $1000 \mathrm{~m}$ a.s.l., net longwave radiation and latent heat flux were both sinks of energy with values in the range of -30 to $-40 \mathrm{~W}$ $\mathrm{m}^{-2}$ compensating the higher sensible heat flux (Fig. 5).

\subsection{Surface ablation rates}

At a glacier scale, along with the previously discussed climatological characteristics, the hypsometry determined a larger area under melt in the west. High melt (values $>5 \mathrm{~m}$ w.e.) in the west occurred over $60 \%$ of the total area, while in the east this magnitude of melt was observed over just $10 \%$ of the total area.

Melt enhancement was found under supraglacial moraine areas on both sides, but with a higher relative impact at the glacier wide-scale in the east. Ice here is covered by relatively thin debris, which is enough to lead to an albedo decrease of 0.1-0.2 (Figs 2, 7). In our SEB model, these areas were parameterised in terms of their albedo and surface roughness. The other turbulence properties on ice-free and supraglacial moraine were treated under the same assumptions (fixed to $0^{\circ} \mathrm{C}$ under positive air temperature, saturated condition on the surface). High sub-debris melt rates have previously been recorded on the eastern Soler Glacier in the NPI (Fukami and Naruse, 1987), suggesting enhanced melt by up to a factor of 2 when compared to bare ice areas at the same elevation. The increase of melt under thin debris-covered areas of the Patagonian glaciers is a potential positive feedback 
on glacier retreat due to the destabilisation of adjacent slopes, increasing the flux of debris over the glacier surface as was reported by Glasser and others (2016) in the NPI between 1987 and 2015. However, in areas with more than a few centimetre thick debris layer, the ice surface is insulated from the atmospheric conditions, hence reducing ablation (e.g. Fyffe and others, 2014).

The high melt rates we present on the western side and at lower elevations on the eastern side exceed those estimated by Schaefer and others (2015) between 1975 and 2011 (Fig. 7a). Apart from the differences in the periods analysed (9 months vs 35 years) there are also differences in the data used (interpolated observations vs gridded climate data), models used and parametrisations (i.e. changes in the albedo due to the supraglacial moraine). Our higher values can be partly accounted for by the fact that summer 2015 and autumn 2016 were characterised by exceptional high incoming shortwave radiation (Garreaud, 2018). Indeed, the surface mass balances estimated in Grey and Tyndall glaciers in the south of the SPI during the hydrological year 2015/16 were the most negative during the period between 2000 and 2016 (Weidemann and others, 2018). Additionally, the lower melt rate evident on the eastern side, in particular in debris-free areas over $\sim 700 \mathrm{~m}$ a.s.l., could be related mainly to the strong cooling effect that the on-glacier observations suggest (Bravo and others, 2019a) and that was included in our computation.

When compared to geodetic mass-balance measurements our simulated ablation appears high. Discrepancies between geodetic mass balance and surface mass balance are to be expected, especially on the lower glacier sections (Weidemann and others, 2018). Abdel-Jaber and others (2019) have previously estimated surface elevation changes that varied between -5 and $-12 \mathrm{~m}$ $\mathrm{a}^{-1}$ over the glaciers in our study area, which assuming an ice density of $900 \mathrm{~kg} \mathrm{~m}^{-3}$, is equivalent to -4.5 to $-10.8 \mathrm{~m}$ w.e. $\mathrm{a}^{-1}$. It should be noted here that our ablation estimates do not capture ice flux effects that geodetic mass-balance measurements obviously include. Indeed, over the western glaciers of our study area it was estimated that the ice flux at $950 \mathrm{~m}$ a.s.l. was $3.27 \mathrm{Gt}$ $\mathrm{a}^{-1}$ while on O'Higgins Glacier the ice flux at $1140 \mathrm{~m}$ a.s.l. was $2.57 \mathrm{Gt} \mathrm{a}^{-1}$ (Gourlet and others, 2016). These estimated ice fluxes partly offset the losses of ablation at the surface.

At the glacier-scale and during the 9 month period, we obtained ablation values of $8.8 \mathrm{~m}$ w.e. (Tempano), $13.7 \mathrm{~m}$ w.e. (Occidental) and $7.7 \mathrm{~m}$ w.e. (Greve). Mernild and others (2016) for these same glaciers obtained ablation annual means (period 1979-2013) of 7.6, 11.3 and $7.1 \mathrm{~m}$ w.e., respectively. This discrepancy is expected to be higher considering the fact that rainfall cannot be disaggregated from the results presented by Mernild and others (2016) as well as the fact that our computation does not include melt events during winter months. For the eastern side glaciers, we obtained means values per glacier of $2.6 \mathrm{~m}$ w.e. (O'Higgins) and $3.7 \mathrm{~m}$ w.e. (Chico). These values are lower than those estimated by Mernild and others (2016), of 6.4 and $6.3 \mathrm{~m}$ w.e. respectively. As mentioned earlier, this discrepancy could be related to the strong cooling effect estimated for this side of the divide (Bravo and others, 2019a). More research is needed to define the spatial variability of the glacier cooling effect over Patagonian and worldwide glaciers in view of its spatial variability and complexity. However, it has been estimated for glaciers elsewhere that the largest offset between on-glacier and off-glacier temperatures occurs under dry, warm and clear sky conditions (Shaw and others, 2021). As these conditions are more frequent to the east than to the west, a stronger glacier cooling effect is expected in the east relative to the west.

\section{Conclusions}

In this study, we have estimated and assessed the energy-balance fluxes, the ablation rates and their spatial differences along a west-east transect for glaciers in the northern sector of the SPI. Using meteorological observations, we conducted a distributed SEB model at hourly time step for the period between October 2015 and June 2016. Our basic principle was that the meteorological variables needed for the model can be spatially distributed through elevation gradients. Hence, a network of five AWSs and three GBL stations, including on-glacier temperature sensors, were taken as representative of the meteorological conditions. Although there are uncertainties in our approach, especially at higher elevations, these unprecedented meteorological observations provide a detailed SEB study over multiple glaciers in the northern part of the SPI. The main findings and conclusions based on our results and discussions are:

(1) During the study period, humid and warm on-glacier conditions prevailed on the western side while dry and cold on-glacier conditions prevailed on the eastern side. These differences are a consequence of the orographic effect widely described in the literature for Patagonia.

(2) The relative importance of each SEB flux varied spatially, but over most of the glacier surface on both sides, sensible heat flux was the main source of energy, followed by net shortwave radiation. Net longwave radiation was a sink of energy, while latent heat flux was either a source or a sink depending on the location.

(3) Favourable conditions for surface ablation exist, especially in terms of surface melt on the lower sections at both sides of the study area. Comparatively, these conditions cause stronger melt rates on the west side glaciers. The spatial extent of the melt is controlled by the hypsometry on each side, showing that there were favourable conditions for a larger area under melt on the west side compared to the east.

On the west side, computed point-scale and glacier-wide melt rates were greater compared with previous modelling efforts, while on the east side, point-scale melt rate were greater at lower elevations, but less at higher elevations and at a glacier-wide scale. Different periods, input data and modelling approaches can explain these differences. Moreover, the severe drought that occurred during the observational period can partly explain the higher melt rate over the western side. Representativeness of the meteorological observations and their distribution, as well as the modelling outputs presented here, especially the turbulent fluxes above $1500 \mathrm{~m}$ a.s.l., must be taken with caution.

Overall, the heterogeneous response of the glaciers that comprise the SPI is determined partly by the spatial variability in the meteorology that exists over this region. Therefore, we understand the SPI as a complex system characterised by highly heterogeneous surface and atmospheric conditions that drive the heterogeneous glacier responses. We recommend avoiding analyses of glacier response to changes in climatic conditions that treat the SPI uniformly, thus neglecting these important spatial variations in meteorological and glaciological conditions.

Supplementary material. The supplementary material for this article can be found at https://doi.org/10.1017/jog.2021.92

Acknowledgements. We acknowledge the Dirección General de Aguas de Chile (DGA) for providing their data for analysis. The Centro de Estudios Científicos (CECs) installed the AWS and GBL stations and provided all the metadata of these stations. CB acknowledges support from the Agencia Nacional de Investigación y Desarrollo (ANID) Programa Becas de Doctorado en el Extranjero, Beca Chile for the doctoral scholarship. AR acknowledges FONDECYT 1171832. The authors thank Dr Bethan Davies and Prof. Ian Brooks for their comments on an earlier version of this manuscript. The authors also thank Dr Marius Schaefer for sharing his data and his 
thorough reviews as well as two further anonymous reviewers and the Scientific Editor Dr Christoph Schneider for his careful evaluation of the manuscript.

\section{References}

Abdel Jaber W, Rott H, Floricioiu D, Wuite J and Miranda N (2019) Heterogeneous spatial and temporal pattern of surface elevation change and mass balance of the Patagonian ice fields between 2000 and 2016 The Cryosphere 13(9), 2511-2535. doi: 105194/tc-13-2511-2019

Ayala A, Pellicciotti F, Peleg N and Burlando P (2017) Melt and surface sublimation across a glacier in a dry environment: distributed energy-balance modelling of Juncal Norte Glacier, Chile. Journal of Glaciology 63(241), 803-822. doi: $10.1017 /$ jog.2017.46

Ayala A, Pellicciotti F and Shea JM (2015) Modelling $2 \mathrm{~m}$ air temperatures over mountain glaciers: exploring the influence of katabatic cooling and external warming. Journal of Geophysical Research: Atmospheres 120, 1-19. doi: 10.1002/2015JD023137

Bolton D (1980) The computation of equivalent potential temperature. Monthly Weather Review 108, 1046-1053. doi: 10.1175/1520-0493(1980) $108<1046$ :TCOEPT>2.0.CO;2

Bonekamp PNJ, van Heerwaarden CC, Steiner JF and Immerzeel WW (2020) Using 3D turbulence-resolving simulations to understand the impact of surface properties on the energy balance of a debris-covered glacier. The Cryosphere 14(5), 1611-1632. doi: 10.5194/tc-14-1611-2020

Box JE and Steffen K (2001) Sublimation on the Greenland ice sheet from automated weather station observations. Journal of Geophysical Research: Atmospheres 106(D24), 33965-33981. doi: 10.1029/2001JD900219

Braun MH and 8 others (2019) Constraining glacier elevation and mass changes in South America. Nature Climate Change 9, 130-136. doi: 10. 1038/s41558-018-0375-7

Braun M and Hock R (2004) Spatially distributed surface energy balance and ablation modelling on the ice cap of King George Island (Antarctica). Global and Planetary Change 42(1-4), 45-58. doi: 10.1016/ jgloplacha200311010

Bravo C and 6 others (2019a) Air temperature characteristics, distribution and impact on modeled ablation for the South Patagonia Icefield. Journal of Geophysical Research: Atmospheres 124(2), 907-925. doi: 10.1029/ 2018JD028857

Bravo C and 6 others (2019b) Assessing snow accumulation patterns and changes on the Patagonian Icefields. Frontiers in Environmental Science 7 (1), 30. doi: 10.3389/fenvs201900030

Brock B and Arnold N (2000) A spreadsheet-based (Microsoft Excel) point surface energy balance model for glacier and snowmelt studies. Earth Surface Processes and Landforms 25(6), 649-658. doi: 10.1002/1096-9837 (200006)25:6<649::AID-ESP97>3.0.CO;2-U

Brock BW, Willis IC and Sharp MJ (2006) Measurement and parameterization of aerodynamic roughness length variations at Haut Glacier d'Arolla, Switzerland. Journal of Glaciology 52(177), 281-297. doi: 10.3189/ 172756506781828746

Brutsaert W (1975) On a derivable formula for long-wave radiation from clear skies. Water Resources Research 11(5), 742-744. doi: 10.1029/ WR011i005p00742

Carturan L, Cazorzi F, De Blasi F and Dalla Fontana G (2015) Air temperature variability over three glaciers in the Ortles-Cevedale (Italian Alps): effects of glacier fragmentation, comparison of calculation methods, and impacts on mass balance modeling. The Cryosphere 9(3), 1129-1146. doi: $10.5194 /$ tc- $9-1129-2015$

Chambers JR and 5 others (2020) Glacial aerodynamic roughness estimates: uncertainty, sensitivity and precision in field measurements. Journal of Geophysical Research: Earth Surface 125(2), e2019JF005167. doi: 10.1029/ 2019JF005167

Cook K, Yang X, Carter C and Belcher B (2003) A modelling system for studying climate controls on mountain glaciers with application to the Patagonian Icefields. Climatic Change 56, 339-367. doi: 10.1023/ A:1021772504938

Cuffey KM and Paterson WSB (2010) The Physics of Glaciers, 4th Edn. Oxford: Butterworth-Heinemann.

Davies BJ and Glasser NF (2012) Accelerating shrinkage of Patagonian glaciers from the Little Ice Age ( $\sim \mathrm{AD} 1870)$ to 2011. Journal of Glaciology 58(212), 1063-1084. doi: 10.3189/2012JoG12J026
De Angelis H (2014) Hypsometry and sensitivity of the mass balance to change in equilibrium-line altitude: the case of the Southern Patagonia Icefield. Journal of Glaciology 60(219), 14-28. doi: 10.3189/2014JoG13J127

De Angelis H, Rau F and Skvarca P (2007) Snow zonation on Hielo Patagónico Sur, southern Patagonia, derived from Landsat 5 TM data. Global and Planetary Change 59(1-4), 149-158. doi: 10.1016/j.gloplacha. 2006.11.032

Ding B and 5 others (2014) The dependence of precipitation types on surface elevation and meteorological conditions and its parameterization. Journal of Hydrology 513, 154-163. doi: 10.1016/j.jhydrol.2014.03.038

Durand $\mathbf{M}$ and 7 others (2019) GPS reflectometry study detecting snow height changes in the Southern Patagonia Icefield. Cold Regions Science and Technology 166, 102840. doi: 10.1016/j.coldregions.2019.102840

Dussaillant I and 8 others (2019) Two decades of glacier mass loss along the Andes. Nature Geosciences 12, 802-808. doi: 10.1038/s41561-019-0432-5

Falaschi D and 6 others (2017) Mass changes of alpine glaciers at the eastern margin of the Northern and Southern Patagonian Icefields between 2000 and 2012. Journal of Glaciology 63(238), 258-272. doi: 10.1017/jog2016136

Falaschi D and 5 others (2019) Six decades (1958-2018) of geodetic glacier mass balance in Monte San Lorenzo, Patagonian Andes. Frontiers in Earth Sciences 7, 326. doi: 10.3389/feart.2019.00326

Foresta L and 7 others (2018) Heterogeneous and rapid ice loss over the Patagonian Ice Fields revealed by CryoSat- 2 swath radar altimetry. Remote Sensing of Environment 211, 441-455. doi: 10.1016/j.rse.2018.03. 041

Fu P and Rich PM (2002) A geometric solar radiation model with applications in agriculture and forestry. Computers and Electronics in Agriculture 37, 2535. doi: 10.1016/S0168-1699(02)00115-1

Fukami H and Naruse R (1987) Ablation of ice and heat balance on Soler Glacier, Patagonia. Bulletin of Glacier Research 4, 37-42.

Fyffe C and 6 others (2014) A distributed energy-balance melt model of an alpine debris-covered glacier. Journal of Glaciology 60(221), 587-602. doi:10.3189/2014JoG13J148

Gardner AS and 15 others (2013) A reconciled estimate of glacier contributions to sea level rise: 2003 to 2009. Science 340 (6134), 852-857. doi: 10. $1126 /$ science. 1234532

Garreaud R (2018) Record-breaking climate anomalies lead to severe drought and environmental disruption in Western Patagonia in 2016. Climate Research 74, 217-229. doi: 10.3354/cr01505

Garreaud R, Lopez P, Minvielle M and Rojas M (2013) Large-scale control on the Patagonian climate. Journal of Climate 26(1), 215-230. doi: 10. 1175/JCLI-D-12-00001.1

Gillett S and Cullen NJ (2010) Atmospheric controls on summer ablation over Brewster Glacier, New Zealand. International Journal of Climatology 31(13), 2033-2048. doi: 10.1002/joc.2216

Glasser NF and 5 others (2016) Recent spatial and temporal variations in debris cover on Patagonian glaciers. Geomorphology 273, 202-216. doi: 10. 1016/j.geomorph.2016.07.036

Gourlet P, Rignot E, Rivera A and Casassa G (2016) Ice thickness of the northern half of the Patagonia Icefields of South America from high-resolution airborne gravity surveys. Geophysical Research Letters 43, 241-249. doi: 10. 1002/2015GL066728

Hock R and Holmgren B (2005) A distributed energy balance model for complex topography and its application to Storglaciären, Sweden. Journal of Glaciology 51(172), 25-36. doi: 10.3189/172756505781829566

Iribarren-Anacona P, Mackintosh A and Norton KP (2015) Hazardous processes and events from glacier and permafrost areas: lessons from the Chilean and Argentinean Andes. Earth Surface Processes and Landforms 40(1), 2-21. doi: 10.1002/esp.3524

Koppes M, Conway H, Rasmussen LA and Chernos M (2011) Deriving mass balance variations and calving variations from reanalysis data and sparse observations, Glaciar San Rafael, northern Patagonia, 1950-2005. The Cryosphere 5, 791-808. doi: 10.5194/tc-5-791-2011

Lenaerts JTM and 6 others (2014) Extreme precipitations and climate gradients in Patagonia revealed by high-resolution regional atmospheric climate modeling. Journal of Climate 27(12), 4607-4621. doi: 10.1175/ JCLI-D-13-00579.1

Lo Vecchio A and 5 others (2019) MODIS image-derived ice surface temperature assessment in the Southern Patagonian Icefield. Progress in Physical Geography: Earth and Environment 43(6), 754-776. doi: 10.1177/ 0309133319851022 
Malz P and 5 others (2018) Elevation and mass changes of the Southern Patagonia Icefield derived from TanDEM-X and SRTM data. Remote Sensing 10(2), 188. doi: 10.3390/rs10020188

Manninen T, Lahtinen P, Anttila K and Riihelä A (2016) Detection of snow surface roughness and hoar at Summit, Greenland, using RADARSAT data. International Journal of Remote Sensing 37(12), 2860-2880. doi: 10.1080/ 01431161.2015 .1131873

Masiokas M and 11 others (2020) Review of the current state and recent changes of the Andean cryosphere. Frontiers in Earth Science 8, 99. doi: 10.3389/feart.2020.00099

Meier WJH, Grießinger J, Hochreuther P and Braun MH (2018) An updated multi-temporal glacier inventory for the Patagonian Andes with changes between the Little Ice Age and 2016. Frontiers in Earth Science 6, 62. doi: 10.3389/feart.2018.00062

Mernild SH, Liston GE, Hiemstra CA and Wilson R (2016) The Andes Cordillera Part III: glacier surface mass balance and contribution to sea level rise (1979-2014). International Journal of Climatology 37(7), 31543174. doi: $10.1002 /$ joc. 4907

Mölg T and 8 others (2020) Mesoscale atmospheric circulation controls of local meteorological elevation gradients on Kersten Glacier near Kilimanjaro summit. Earth System Dynamics 11, 653-672. doi: 10.5194/esd-11-653-2020

Mölg T, Cullen NJ and Kaser G (2009) Solar radiation, cloudiness and longwave radiation over low-latitude glaciers: implications for mass balance modeling. Journal of Glaciology 55(190), 292-302. doi: 10.3189/002214309788608822

Monahan P and Ramage J (2010) AMSR-E melt patterns on the Southern Patagonian Icefield. Journal of Glaciology 56(198), 699-708. doi: 10.3189/ 002214310793146197

Mouginot J and Rignot E (2015) Ice motion of the Patagonian icefields of South America: 1984-2014. Geophysical Research Letters 42(5), 14411449. doi: $10.1002 / 2014$ GL062661

Muñoz-Sabater J and 16 others (2021) ERA5-Land: a state-of-the-art global reanalysis dataset for land applications. Earth System Science Data Discussions [preprint]. doi:10.5194/essd-2021-82, in review.

Murray FW (1967) On the computation of saturation vapor pressure. Journal of Applied Meteorology 6(1), 203-204. doi: 10.1175/1520-0450(1967) 006<0203:OTCOSV>2.0.CO;2

Nicholson L and Stiperski I (2020) Comparison of turbulent structures and energy fluxes over exposed and debris-covered glacier ice. Journal of Glaciology 66 (258), 1-13. doi: 10.1017/jog.2020.23

Oerlemans J and Klok EJ (2002) Energy balance of a glacier surface: analysis of Automatic Weather Station data from the Morteratschgletscher, Switzerland. Arctic, Antarctic and Alpine Research 34(4), 477-485. doi: 10.1080/15230430.2002.12003519

Oerlemans J and Knap WH (1998) A one-year record of global radiation and albedo from the ablation zone of the Morteratschgletscher, Switzerland. Journal of Glaciology 44(147), 231-238. doi: 10.3189/S0022143000002574

Ohata T and 5 others (1985) The east-west contrast in meteorological conditions and its effect on glacier ablation. Bulletin of Glaciological Research 3, 52-53.

Oke TR (1987) Boundary Layer Climate, 2nd Edn. London: Routledge Press.

Pellicciotti F, Ragettli S, Carenzo M and McPhee J (2014) Changes of glaciers in the Andes of Chile and priorities for future work. Science of the Total Environment 493, 1197-1210. doi: 10.1016/j.scitotenv.2013.10.055

Raleigh MS, Landry CC, Hayashi M, Quinton WL and Lundquist JD (2013) Approximating snow surface temperature from standard temperature and humidity data: new possibilities for snow model and remote sensing evaluation. Water Resources Research 49(12), 8053-8069. doi: 10.1002/ 2013WR013958

Rasmussen LA, Conway H and Raymond CF (2007) Influence of upper air conditions on the Patagonia icefields. Global Planet Change 59(1-4), 203-216. doi: 10.1016/j.gloplacha.2006.11.025

Rignot E, Rivera A and Casassa G (2003) Contribution of the Patagonia Icefields of South America to sea level rise. Science (New York, N.Y.) 302 (5644), 434-436. doi: 10.1126/science. 1087393
Sagredo E and Lowell T (2012) Climatology of Andean glaciers: a framework to understand glacier response to climate change. Global and Planetary Change 86-87, 101-109. doi: 10.1016/j.gloplacha.2012.02.010

Sauter T and Galos SP (2016) Effects of local advection on the spatial sensible heat flux variation on a mountain glacier. The Cryosphere 10, 2887-2905. doi: 10.5194/tc-10-2887-2016

Schaefer M, Fonseca D, Farias-Barahona D and Casassa G (2020) Surface energy fluxes on Chilean glaciers: measurements and models. The Cryosphere 14, 2545-2565. doi: 10.5194/tc-14-2545-2020

Schaefer M, Machguth H, Falvey M, Casassa G and Rignot E (2015) Quantifying mass balance processes on the Southern Patagonia Icefield. The Cryosphere 9(1), 25-35. doi: 10.5194/tc-9-25-2015

Schmidt RA (1982) Vertical profiles of wind speed, snow concentration and humidity in blowing snow. Boundary Layer Meteorology 23, 223-246.

Schneider C and 5 others (2003) Weather observations across the Southern Andes at 53 ${ }^{\circ}$ S. Physical Geography 24(2), 97-119. doi: 10.2747/0272-3646. 24.2.97

Schneider C, Kilian R and Glaser M (2007) Energy balance in the ablation zone during the summer season at the Gran Campo Nevado Ice Cap in the Southern Andes. Global and Planetary Change 59, 175-188. doi: 10. 1016/j.gloplacha.2006.11.033

Schwikowski M, Schläppi M, Santibañez P, Rivera A and Casassa G (2013) Net accumulation rates derived from ice core stable isotope records of Pío XI glacier, Southern Patagonia Icefield. The Cryosphere 7, 1635-1644. doi: 10.5194/tc-7-1635-2013

Shaw TE and 5 others (2021) Distributed summer air temperatures across mountain glaciers in the south-east Tibetan Plateau: temperature sensitivity and comparison with existing glacier datasets. The Cryosphere 15, 595-614. doi: 10.5194/tc-15-595-2021

Shea JM and Moore RD (2010) Prediction of spatially distributed regional-scale fields of air temperature and vapour pressure over mountain glaciers. Journal of Geophysical Research: Atmospheres 115(D23107), 1-15. doi: 10.1029/2010JD014351.

Sicart JE, Hock R, Ribstein P and Chazarin JP (2010) Sky long-wave radiation on tropical Andean glaciers: parameterization and sensitivity to atmospheric variables. Journal of Glaciology 56(199), 854-860. doi: 10. 3189/002214310794457182

Smith R and Evans J (2007) Orographic precipitation and water vapor fractionation over the Southern Andes. Journal of Hydrometeorology 8(1), 3 19. doi: 10.1175/JHM555.1

Takeuchi Y, Naruse R and Satow K (1995) Characteristics of heat balance and ablation on Moreno and Tyndall glaciers, Patagonia, in the summer 1993/ 94. Bulletin of Glacier Research 13, 45-56.

Takeuchi Y, Naruse R, Satow K and Ishikawa N (1999) Comparison of heat balance characteristics at five glaciers in the Southern Hemisphere. Global Planet Change 22, 201-208. doi: 10.1016/S0921-8181(99)00037-5

Wallace JM and Hobbs PV (2006) Atmospheric Science: An Introductory Survey, 2nd Edn. Amsterdam, Boston: Elsevier Academic Press.

Weidemann SS and 6 others (2018) Glacier mass changes of lake-terminating Grey and Tyndall glaciers at the Southern Patagonia Icefield derived from geodetic observations and energy and mass balance modeling. Frontiers in Earth Science 6, 81. doi: 10.3389/feart.2018.00081

White A and Copland L (2015) Decadal-scale variations in glacier area changes across the Southern Patagonian Icefield since the 1970s. Arctic, Antarctic, and Alpine Research 47(1), 147-167. doi: 10.1657/AAAR0013-102

Willis M, Melkonian A, Pritchard M and Rivera A (2012) Ice loss from the Southern Patagonian Ice Field, South America, between 2000 and 2012. Geophysical Research Letters 39(17), L17501. doi: 10.1029/2012GL053136

Wilson, R and 6 others (2018) Glacial lakes of the Central and Patagonian Andes. Global and Planetary Change 162, 275-291. doi: 10.1016/j.gloplacha.2018.01.004

Zemp M and 14 others (2019) Global glacier mass changes and their contributions to sea-level rise from 1961 to 2016. Nature 568, 382-386. doi: 10. 1038/s41586-019-1071-0 